\title{
Molecular Characteristics of RAGE and Advances in Small-Molecule Inhibitors
}

\author{
Hyeon Jin $\operatorname{Kim}^{1} \mathbb{D}$, Mi Suk Jeong ${ }^{2, *}$ and Se Bok Jang ${ }^{1, *}$ \\ 1 Department of Molecular Biology, College of Natural Sciences, Pusan National University, Jangjeon-dong, \\ Geumjeong-gu, Busan 46241, Korea; khjkhj0903@naver.com \\ 2 Insitute for Plastic Information and Energy Materials and Sustainable Utilization of Photovoltaic Energy \\ Research Center, Pusan National University, Jangjeon-dong, Geumjeong-gu, Busan 46241, Korea \\ * Correspondence: 123misuk@pusan.ac.kr (M.S.J.); sbjang@pusan.ac.kr (S.B.J.); \\ Tel.: +82-51-510-2523 (M.S.J. \& S.B.J); Fax: +82-51-581-2544 (M.S.J. \& S.B.J.);
}

Citation: Kim, H.J.; Jeong, M.S.; Jang, S.B. Molecular Characteristics of RAGE and Advances in Small-Molecule Inhibitors. Int. J. Mol. Sci. 2021, 22, 6904. https://doi.org/ $10.3390 /$ ijms 22136904

Academic Editor: Béatrice Charreau

Received: 26 May 2021

Accepted: 24 June 2021

Published: 27 June 2021

Publisher's Note: MDPI stays neutral with regard to jurisdictional claims in published maps and institutional affiliations.

Copyright: (C) 2021 by the authors Licensee MDPI, Basel, Switzerland. This article is an open access article distributed under the terms and conditions of the Creative Commons Attribution (CC BY) license (https:// creativecommons.org/licenses/by/ $4.0 /)$

\begin{abstract}
Receptor for advanced glycation end-products (RAGE) is a member of the immunoglobulin superfamily. RAGE binds and mediates cellular responses to a range of DAMPs (damage-associated molecular pattern molecules), such as AGEs, HMGB1, and S100/calgranulins, and as an innate immune sensor, can recognize microbial PAMPs (pathogen-associated molecular pattern molecules), including bacterial LPS, bacterial DNA, and viral and parasitic proteins. RAGE and its ligands stimulate the activations of diverse pathways, such as p38MAPK, ERK1/2, Cdc42/Rac, and JNK, and trigger cascades of diverse signaling events that are involved in a wide spectrum of diseases, including diabetes mellitus, inflammatory, vascular and neurodegenerative diseases, atherothrombosis, and cancer. Thus, the targeted inhibition of RAGE or its ligands is considered an important strategy for the treatment of cancer and chronic inflammatory diseases.
\end{abstract}

Keywords: RAGE; multi-ligands; disease; drug; inhibitor

\section{Introduction}

RAGE (receptor for advanced glycation end-products) was first isolated from the human lung library in 1992 and noted for its ability to act as a receptor for advanced glycation end products (AGEs). RAGE is a transmembrane protein of the immunoglobulin (Ig) superfamily of cell surface molecules [1], and interacts with multiple ligands that mediate cellular responses to a range of DAMPs (damage-associated molecular pattern molecules), such as AGEs, the S100 group of proteins, HMGB1 (high mobility group box-1 protein), amyloid $\beta$, and DNAs, and also acts as an innate immune sensor of PAMPs (pathogen-associated molecular pattern molecules), such as bacterial LPS, respiratory viruses, viral and parasitic proteins, and bacterial DNA [2-12]. Ligand stimulation of RAGE activates signal transduction pathways, such as the diaphanous-related formin 1 (DIAPH1), mitogen-activated protein kinase (MAPK), phosphatidylinositol 3-kinase (PI3K)/AKT, and Toll-interleukin 1 receptor domain-containing adaptor protein (TIRAP) pathways, which result in RAGEdependent NF- $\mathrm{KB}$ activation [13-19]. RAGE is expressed in many cell types, including endothelial, vascular smooth muscle, and cancer cells monocyte/macrophages, granulocytes, and adipocytes [20]. Upregulated RAGE expression has been reported in diabetes mellitus, atherosclerosis, rheumatoid arthritis, Alzheimer's disease (AD), cardiovascular diseases (CVDs), and immune/inflammatory diseases [21-25], and has also been shown to be related to the developments and progressions of different cancer types [26].

\section{Structure and Isoforms of RAGE}

RAGE is a $50-55 \mathrm{kDa}$ glycosylated protein that contains an extracellular (amino acids 23-342), a hydrophobic transmembrane (residues 343-363), and a cytoplasmic (residues 363-404) domain. The extracellular structure of RAGE is composed of a variable (V) 
immunoglobulin (Ig) domain (residues 23-116) and two constant C1 (residues 124-221) connected to $\mathrm{C} 2$ (residues 227-317) Ig domains by a flexible seven amino acid linker [27]. Its $\mathrm{V}$ domain consists of eight strands $\left(\mathrm{A}^{\prime}, \mathrm{B}, \mathrm{C}, \mathrm{C}^{\prime}, \mathrm{E}, \mathrm{F}\right.$, and $\left.\mathrm{G}\right)$ connected by six loops that form two beta-sheets linked by a disulfide bridge between Cys38 (strand B) and Cys 99 (strand F) [28]. The molecular surfaces of V-C1 domains are covered by a hydrophobic cavity and contain many highly positively charged Arg and Lys residues [17]. In contrast, the $\mathrm{C} 2$ domain is composed of acidic amino acids and carries a negative surface charge (Figure 1) [29]. Multiple RAGE ligands contain highly negatively charged regions and can bind to the positively charged V-C1 domain [7]. Ding Xu reported that heparan sulfate plays a crucial role in stabilizing RAGE homodimerization the self-association of V-V domains and RAGE hexamerization [30]. In its monomeric state, RAGE has only weak affinity for several ligands, and thus, it appears that its multimerization is necessary for ligand binding. RAGE oligomerizations through its C1-C1 domains, C2-C2 domains, and/or TM helix dimerization are important steps for RAGE signaling after ligand binding [30-32]. The transmembrane helical structure of RAGE contains the meticulously conserved GxxxG motif, which promotes helix-helix homodimerization and may be involved in signal transduction [33]. The cytoplasmic domain of RAGE exhibits high sequence identity with primates and rodents, which is essential for RAGE ligand-mediated signal transduction [1], and its cytoplasmic domain contains a highly acidic region that is capable of binding several molecules. In fact, truncation of this domain abolishes downstream RAGE signaling and attenuates RAGE-associated pathologic effects [34,35].

The human RAGE gene is located on chromosome 6 in the MHC (major histocompatibility complex) class III region, which contains many genes that impact the adaptive and innate immune systems [29]. More than 20 RAGE isoforms with diverse biological functions have been found to result from alternative splicing [36]. In addition, polymorphisms in RAGE have been suggested to be potential biomarkers in RAGE-relevant diseases [37,38], and the RAGE transcript has been identified as the target for the productions of alternative splicing generates isoforms, such as full-length RAGE (FL-RAGE), dominant-negative RAGE (DN-RAGE, residues 23-363), N-truncated RAGE (N-RAGE, 124-404), C-truncated soluble RAGE (sRAGE, 23-342), and splice variant endogenous secretory RAGE (esRAGE) [39]. The functions of these truncated RAGE isoforms have yet to be elucidated, but it has been established the dysregulations of RAGE isoforms and their ligands lead to the development of a number of human diseases [40,41]. Soluble RAGE may competitively inhibit RAGE-ligand-mediated signaling, and a low sRAGE level has been suggested to be a biomarker for diseases [7]. On the other hand, serum levels of sRAGE in diabetes, sepsis, and end-stage renal disease (ESRD) are elevated [42,43]. 


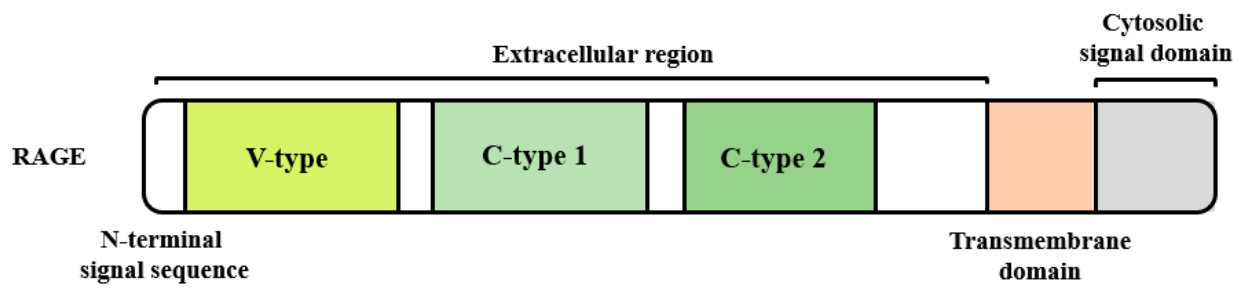

(A)

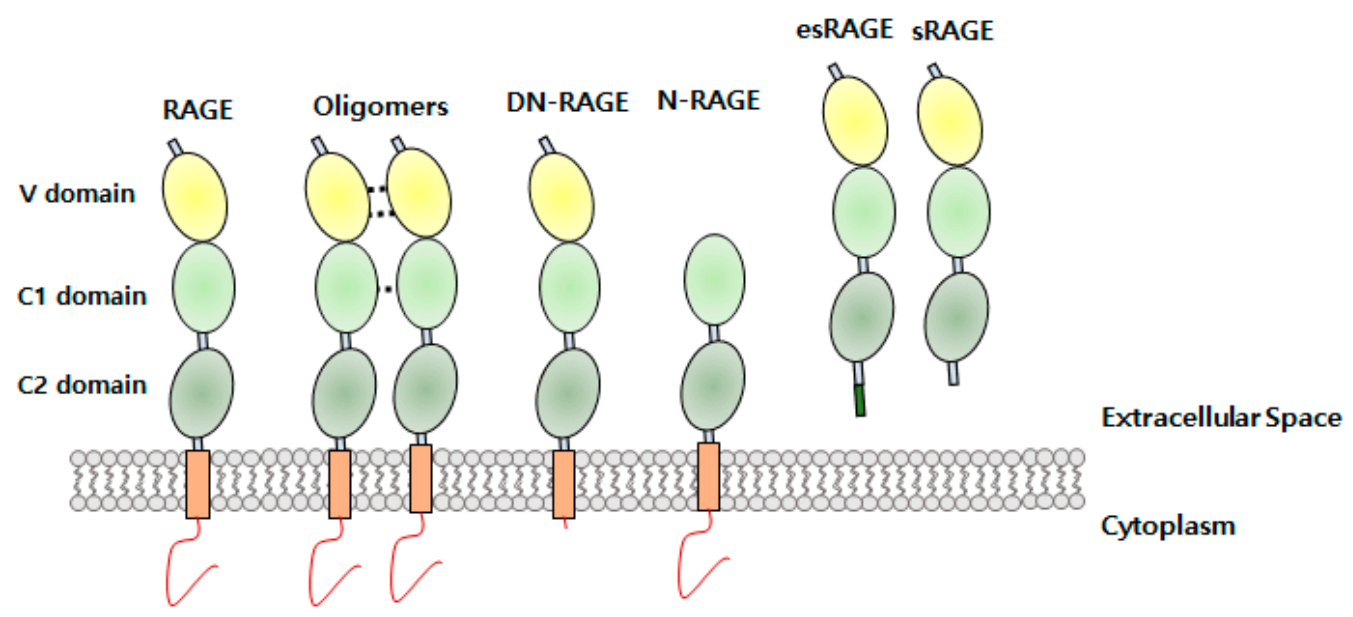

(B)
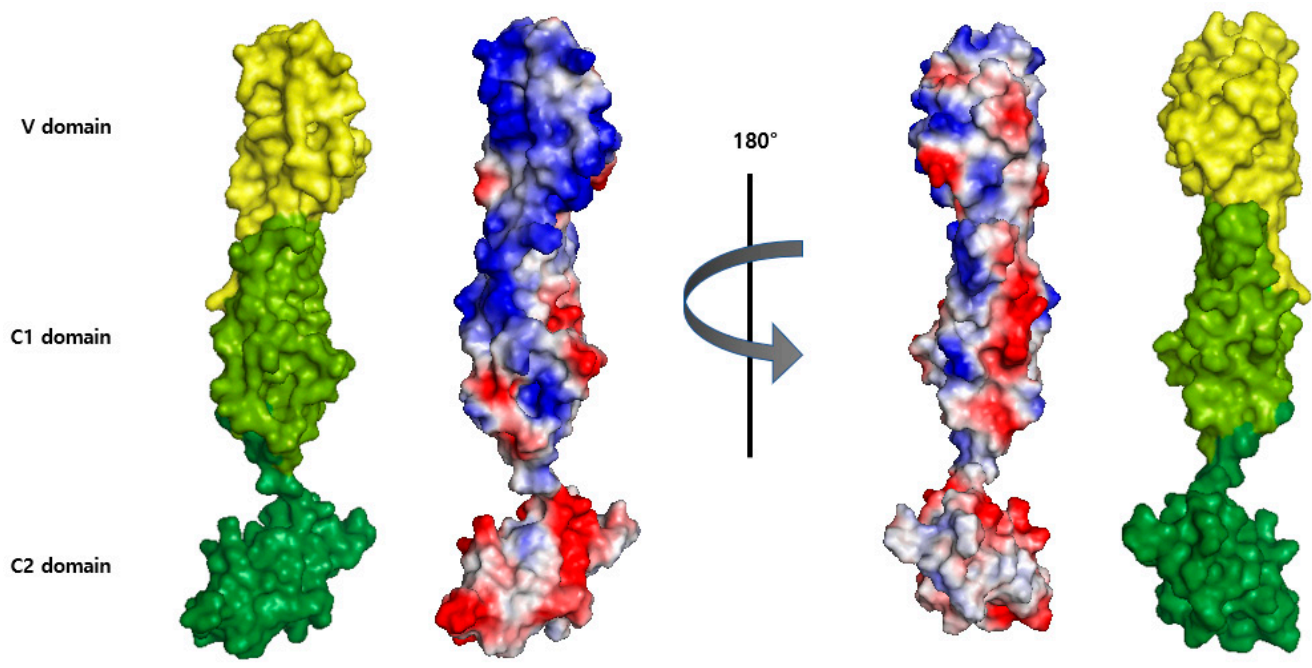

(C)

Figure 1. Structural analyses of RAGE. (A) Schematic representation of full-length RAGE domain. RAGE consists of a variable (V) domain, two constant (C1 and C2) domains, a transmembrane region, and a cytoplasmic tail. (B) RAGE isoforms. RAGE isoforms in the illustration include (from left to right) full-length RAGE, oligomers, dominant-negative RAGE (DN-RAGE), N-truncated RAGE (N-RAGE), endogenous secretory (esRAGE), and soluble form RAGE (sRAGE). (C) The surface of RAGE colored according to electrostatic charges (PDB ID: 4YBH). Positively charged areas are shown in blue, and negative charged areas in red. The figure was prepared using PyMOL.

\section{RAGE as a Multi-Ligand Receptor}

RAGE binds diverse classes of ligands, such as HMGB1, S100 calcium-binding protein/calgranulin, amyloid- $\beta$, and lysophosphatidic acid (LPA) [3,5,22,44-47]. RAGE expression can also increase DNA internalization and augment the Toll-like receptors (TLR) response through TLR9 $[48,49]$. Ligand engagement of RAGE activates multiple signaling pathways, including those of ERK, AKT, STAT3, JNK and MAPK, which result in the 
activations of transcription factors, including NF- $\mathrm{KB}[50,51]$. Furthermore, interactions between RAGE and multiple ligands upregulate RAGE through positive feedback loops [52], and following RAGE activation are expressed on various cell types, including endothelial cells, vascular smooth muscle cells, lymphocytes, neurons, monocytes/macrophages, and podocytes [20,35,53-55]. Moreover, ligand-RAGE interactions are involved in the pathogeneses of diabetes mellitus, chronic renal failure, rheumatoid arthritis, atherosclerosis, neurodegenerative diseases, cancer, immune/inflammatory responses, and aging [56-63]. Ligands of RAGE are listed in Table 1.

Table 1. Significant RAGE ligands.

\begin{tabular}{|c|c|c|c|}
\hline RAGE Ligands & RAGE Binding Domain & Clinical Significance & Ref. \\
\hline \multicolumn{4}{|c|}{ Endogenous RAGE Ligands } \\
\hline AGEs & $\mathrm{V}$ & Diabetes, chronic inflammation and cancer & [28] \\
\hline S100/calgranulins & $\mathrm{V}$ or $\mathrm{VC} 1$ or $\mathrm{V} 2$ & Inflammatory response and cancer differentiation and progression & [64] \\
\hline HMGB1 & $\mathrm{VC} 1 \mathrm{C} 2$ & Cancer development and metastasis and drug resistance & [65] \\
\hline$\beta$-sheet fibrils & $\mathrm{V}$ & Neuronal disease: Alzheimer's disease & [66] \\
\hline Mac1 & & RAGE-mediated leukocyte recruitment & [45] \\
\hline Quinolinic acids & VC1 & Neuronal disease: Huntington's disease & [67] \\
\hline LPA & $\mathrm{V}$ & Cell proliferation and migration in C6 glioma and smooth muscle cells & [68] \\
\hline PS & & Rac1 activation in alveolar macrophages & [69] \\
\hline $\mathrm{C} 1 \mathrm{q}$ & & Recruitment of leukocytes and phagocytosis & [70] \\
\hline mDia1 & cytoplasmic & Initiation and activation of RAGE-mediated signaling & [13] \\
\hline \multicolumn{4}{|c|}{ Exogenous RAGE Ligands } \\
\hline RNA or DNA & VC1 & RAGE-mediated augmentation of inflammation & [8] \\
\hline RSV F protein & VC1 & Promote the survival of RSV-infected cells & [11] \\
\hline Longistatin & $\mathrm{V}$ & Longistatin acts as an antagonist to RAGE and suppresses inflammation & [12] \\
\hline
\end{tabular}

AGEs: Advanced glycation end-products; HMGB1: High mobility group box-1 protein; LPA: Lysophosphatidic acid; PS: Phosphatidylserine; mDia1: Mammalian diaphanous 1; RSV: Respiratory syncytial virus.

\subsection{Endogenous RAGE}

Many types of AGE have been identified, and aging leads to accumulations of AGEs in tissues and plasma [71]. $N_{\varepsilon}$-carboxymethyl-lysine (CML) and $N_{\varepsilon}$-carboxyethyl-lysine (CEL) are found in human tissue and blood plasma and bind to the V domain of RAGE. Interactions between AGEs and RAGE induce the expressions of pro-inflammatory cytokines and chemokines, such as TNF- $\alpha$, IL-1 $\beta$, and CCL2 [72,73], and have been linked with the complications of diabetes, chronic inflammation, Alzheimer's disease, and cancer [28]. Methylglyoxal (2-oxoaldehyde) is a precursor of AGEs and a reactive $\alpha$-oxaldehyde. RAGE binds to three structural isomers of methylglyoxal-derived hydroimidazolones (MG-H), that is, MG-H1 [N $\delta$-(5-hydro-5-methyl-4-imidazolon-2-yl) ornithine], MG-H2 [5-(2-amino-5-hydro-5-methyl-4-imidazolon-1-yl) norvaline], and MG-H3 [5-(2-amino4-hydro-4-methyl-5-imidazolon-1-yl)- norvaline], and binding between the V-domain of RAGE and MG-H increases the phosphorylation of c-Jun $N$-terminal kinase (JNK) in vitro [74].

The S100 protein family contains 25 members with different expression patterns, functions, and oligomeric states, and S100B, S100A1, S100A2, S100A4, S100A5, S100A5, S100A6, S100A7, S100A8/A9, S100A11, S100A12, and S100P have been shown to interact with RAGE in vivo [2]. The $\mathrm{S} 100$ proteins are small proteins (9-13 $\mathrm{kDa}$ ) that bind calcium via EF-hand domains and act as calcium sensors, which participate in calcium signal transduction. They are also involved in the regulation of several cellular processes, such as cell differentiation and progression in invertebrates. Most S100 calcium-binding protein genes 
are located in human chromosome 1q21, which tends to exhibit physical chromosomal rearrangements [75]. S100 proteins interact and regulate various proteins involved in the dynamics of cytoskeletal constituents, calcium homeostasis, cell growth, and differentiation. S100B is mainly expressed in the brain and is well expressed and secreted by astrocytes, Schwann cells, and oligodendrocytes $[64,76,77]$. Extracellular S100B proteins bind to the RAGE V-domain and recruit PI3K/AKT and NF- $\mathrm{KB}$ [78], and these interactions induce trophic and inflammatory responses by neurons and carcinogenesis [78-80]. S100A1 is primarily expressed in the heart and only marginally expressed in other tissues [81]. S100B and S100A1 were reported to interact with RAGE on cell surfaces, inducing neurite outgrowth, and increase cell survival in a HMGB1 dependent manner [82]. S100A2 has been shown to interact with and increase the transcriptional activity of tumor suppressor protein $\mathrm{p} 53$, and is downregulated in many cancers, including prostate, oral, melanoma, lung, and breast cancer [83-88]. However, it is upregulated in other cancers, such as gastric, esophageal squamous carcinoma, non-small lung carcinoma, and ovarian cancer [89-92]. Leclerc demonstrated that S100A2 interacts with the V-domain of RAGE [2]. The binding between S100A4 and RAGE increased the production of matrix metalloproteinase 13 (MMP-13), which requires modulation of intracellular calcium levels [93]. S100A5 interacts with the RAGE V-domain in a calcium-dependent manner and is highly expressed in astrocytic tumors [94]. S100A6 is found at high levels in the lungs, kidneys, muscles, spleen, and the brain, and is overexpressed and plays important roles in many cancers including melanoma, lung cancer, hepatocellular carcinoma, colorectal cancer, and gastric cancer [84,95-101]. S100A6 interacts with the V and C2 domains of RAGE and activates JNK signaling [78]. RAGE-S100A7 (psoriasin) mediates chemotaxis and is involved in the regulation of pro-inflammatory and antimicrobial functions [102]. S100A8 (calgranulin A, also known as MRP8) and S100A9 (calgranulin B, also known as MRP14) are strongly expressed by cells of myeloid origin, epithelial cells, and keratinocytes during inflammation. S100A8/A9 can form heterodimers or hetero-tetramers in the absence or presence of calcium, respectively [103-106]. High levels of S100A8/9 have been found in Alzheimer's disease, rheumatoid arthritis, Crohn's disease, cystic fibrosis, and several cancers, such as colorectal carcinoma, prostate cancer, and gastric cancer [107-113]. Although the RAGE/S100A8/A9 interaction is unclear, it is known to promote cell growth via p38MAPK, p44/42 kinase, and NF- $\mathrm{kB}$ in tumor cells [114,115]. S100A11 levels are elevated in prostate, breast, and pancreatic cancer; however, S100A11 acts as a tumor suppressor in bladder and renal carcinomas. Furthermore, S100A11-RAGE signaling modulates the pathogenesis of osteoarthritis (OA) by regulating differentiation to hypertrophy [116-121]. S100A12 (calgranulin A) is highly expressed in inflammatory diseases, such as cystic fibrosis, atherosclerosis, psoriasis, rheumatoid arthritis, Crohn's disease, and Kawasaki disease [122-127]. S100A12 promotes intracellular signal transduction in neurons involving the MAPK and phospholipase C pathways [128]. SPR showed S100A12 interacts with the V-domain of RAGE [2]. The interaction between S100A13 and RAGE has not been revealed, though it is known S100A13 translocates from nucleus to cytoplasm and that this leads to the extracellular secretion of endothelial cells in a RAGE dependent-manner [129]. S100A13 mRNA has been reported in many tissues and organs including kidneys, ovaries, spleen, brain, and heart. This AGE is a marker of angiogenesis in human astrocytic gliomas and invasive lung cancer [130-133]. S100P is present in breast, gastric, ovarian, pancreatic, and prostate cancer and colorectal carcinoma [134-136], and the S100P-RAGE interaction activates ERK and NF- $\mathrm{KB}$ signaling pathways in NIH3T3 cells [137].

HMGB1 is a highly conserved nuclear protein that acts as a chromatin-binding factor, and this binding leads to the bending of DNA and the promotion of DNA transcription [138]. HMGB1 is passively released by necrotic cells and actively secreted by inflammatory cells. Extra HMGB1 binds with high affinity to several receptors including TLR-2, TLR4 , and RAGE on endothelial, smooth muscle and cancer cells and neutrophils $[65,139,140]$. HMGB1 overexpression is a hallmark of sepsis, arthritis, neurodegeneration, aging, angiogenesis, and cancer development and metastasis [141-145]. Interaction between RAGE 
and HMGB1 promotes the activations of tumor cell signaling pathways, such as those of ERK1/2, p38MAPK, and NF-KB, and results in cancer progression and metastasis $[146,147]$. Recent studies have revealed that HMGB1-RAGE signaling triggers ERK-mediated mitochondrial Drp1 phosphorylation leading to autophagy for chemoresistance and regrowth in colorectal cancer [148]. RAGE also binds amyloid- $\beta$ peptides (A $\beta 40$ and $A \beta 42)$, which form aggregates in the brain and promote neurodegeneration [5] and may also act as mediators of disease progression in AD by interacting with $A \beta$ and transporting it across the blood-brain barrier (BBB). In addition, these bindings result in the expressions of pro-inflammatory cytokines and endothelin-1 [66].

Quinolinic acid, a neuroactive metabolite of the kynurenine pathway, is an agonist of the N-methyl-D-aspartate (NMDA) receptor and is normally present at nanomolar concentrations in human brain and cerebrospinal fluid (CSF). Excessive quinolinic acid levels have been implicated in a variety of human neurological diseases, including AD and Huntington's disease [67]. The direct interaction between quinolinic and the VC1 domain of RAGE is involved in early responses to noxious stimuli and may be associated with signaling cascades leading to cell death [6].

Endothelial RAGE interacts with Mac-1 on leukocytes [45], and Orlova et al. reported HMGB1 dose-dependently enhanced the interaction between Mac-1 and RAGE and induced the activation of NF- $\mathrm{KB}$ in neutrophils [47].

Lysophosphatidic acid (LPA) is a serum phospholipid with growth factor-like activities in many cell types. LPA stimulates cell migration, proliferation, and survival by acting on its cognate G-protein-coupled receptors [149]. Furthermore, RAGE was found to be required for LPA-mediated signal transduction, leading to proliferation and migration, in C6 glioma cells and smooth muscle cells [68].

Phosphatidylserine (PS) is a structural component of nuclear envelopes, endoplasmic reticulum, the inner cytosolic region of plasma membranes, myelin, and Golgi apparatus [150]. Cells undergoing apoptosis display PS on their surfaces, and this acts as a signal for the induction of phagocytosis and is recognized by receptors of lysosomal phagocytic vesicles. RAGE-deficient alveolar macrophages showed harmed apoptotic thymocytes and resulted in the defective clearance of apoptotic neutrophils in RAGE-deficient mice. PS-RAGE binding plays an important role in the GTPase and Rac1 signaling pathways. Details of the PS-RAGE interaction are still being explored and the molecular mechanism has not been determined [69].

Complement protein $\mathrm{Clq}$ binds to microbial surfaces or immune complexes, and thus, stimulates the complementation system and the productions of membrane lytic complexes, opsonins, and anaphylatoxins. Surface plasmon resonance (SPR) showed RAGE and C1q interact directly with a $\mathrm{Kd}$ of $5.6 \mu \mathrm{M}$, and this interaction plays a role in adaptive immunity and promotes C1q-mediated phagocytosis [70].

The recognition of DNA and RNA derived from hosts or pathogens is one way the innate immune system responds to infection and tissue damage. RAGE promotes DNA uptake by endosomes and augments TNR response through TLR9 [8]. TIRAP and myeloid differentiation primary response gene 88 (MyD88) are TLR2/4 adaptor proteins, and these proteins induce AKT, p38, IKK $\alpha$, and JNK. Sakaguchi et al. demonstrated that bindings between phosphorylated RAGE and TIRAP or MyD88 result in the transduction of downstream signals [151]. Furthermore, RAGE-TLR crosstalk is involved in chronic inflammatory reactions and is considered a potential target for the treatment of neurodegenerative disorders [152].

\subsection{Exogenous RAGE Ligands}

RAGE plays a role in immune reactions by recognizing and responding to various PAMPs, including bacterial lipopolysaccharide (LPS), bacterial DNA, and viral and parasitic proteins. LPS is a major component of the cell walls of Gram-negative bacteria and initiates inflammatory cascades leading to sepsis. RAGE directly interacts with LPS and is involved in LPS-induced NF- $\mathrm{kB}$ activation and endothelial hyperpermeability $[10,153]$. 
The VC1 domain of RAGE can bind 22-nt dsDNA derived from vaccinia virus and a 22mer CpG motif-containing dsDNA [8]. Human respiratory syncytial virus (RSV) is a major cause of severe respiratory tract infections. The RSV fusion (F) protein mediates fusion between the viral envelope and airway epithelial cells. RAGE binds F protein and enables RSV infection of airway epithelial cells [11]. Longistatin secreted in saliva of the tick Haemaphysalis longicornis also binds to RAGE. Longistatin acts as a RAGE antagonist, suppresses NF- $\mathrm{kB}$ translocation, and thus, hosts immune response [12].

\section{RAGE Ligand Signaling}

Although many extracellular ligands interact with the VC1 domain of RAGE, the cytoplasmic domain of RAGE plays a vital role in RAGE-mediated signaling and overall RAGE function. RAGE activates diverse intracellular signaling pathways, including those of p38MAPK, AKT, ERK, mammalian diaphanous 1 (mDia1), and Rho GTPase (Rac1, Cdc42), and these pathways activate cascade transcription factors, such as NF-kB, SP-1, STAT3, and EGR-1 $[7,51,154]$. RAGE activates various signals by binding with adaptor proteins, such as mDia1, PKC $\zeta$, ERK1/2, dedicator of cytokinesis 7 (DOCK7), and DIAPH1 [13-16,151,155]. This interaction blockade presents a novel potential therapeutic target (Figure 2).

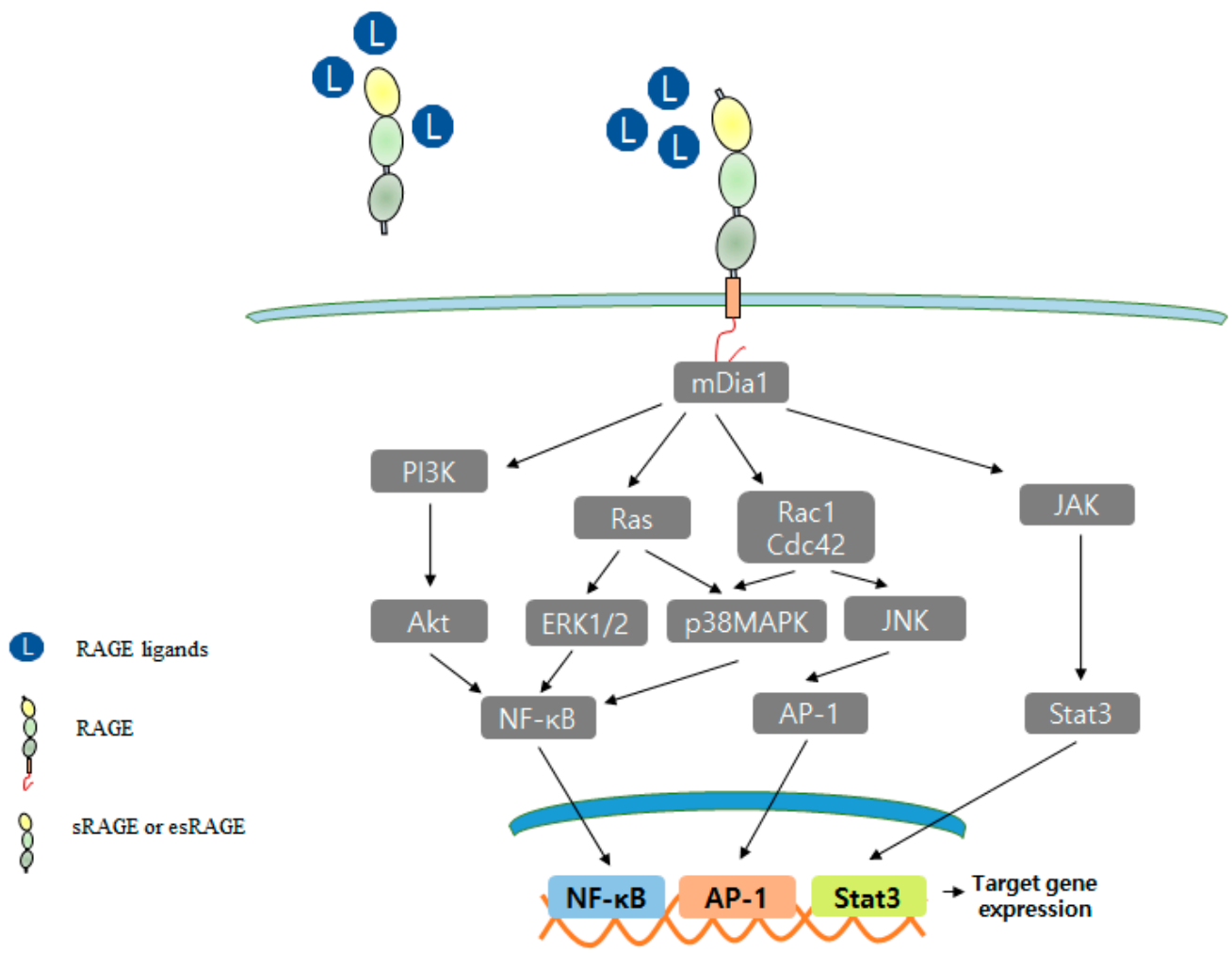

Figure 2. RAGE signal transduction pathway. RAGE interacts with a diverse spectrum of extracellular ligands and multiple signal transduction pathways, including PI3K, p28MAPK, Rho GTPase, Rac1, and JAK pathways. At the transcriptional level, NF- $\mathrm{BB}, \mathrm{AP}-1$, and Stat3 have upregulated as vital targets of RAGE signaling, nevertheless other transcription factors.

The cytoplasmic domain of RAGE binds with formin homology domain-1 (FH-1) of mDia1 [13], and the role of RAGE-mDia1 signaling is regulated during vascular smooth muscle cell (SMC) signal transduction and migration [156]. The S100B/RAGE/mDia1 pathway was reported to induce the migration of microglia via the activations of Rac1, JNK, and AP-1 and to result in the upregulations of the chemokines, CCL3, CCL5, and CXCL12 [157]. RAGE-mDia1 signaling also mediates the activations of Rac1 and Cdc42 during C6 glioma cell migration [15], and RAGE-mDia1 activates PKC $\beta I I$, ERK1/2, and JNK signaling and regulates Egr-1 in hypoxic macrophages [158]. 
Ishihara et al. revealed by immunoprecipitation that ERK $1 / 2$ interacts with the cytoplasmic region of RAGE in HT1080 cells [16]. The release of HMGB1 from dying cancer cells enhances regrowth and chemoresistance via RAGE-ERK signaling, and the RAGE-ERK pathway activates the phosphorylation of Drp1 at residue S616, thus triggering autophagy for chemoresistance and regrowth in surviving colorectal cancer cells [148]. RAGE has four potential phosphorylation sites at Ser391, Ser399, SER400, and Thr401. Of these, only Ser391 is conserved in humans, mice, rats, guinea pigs, rabbits, cats, and dogs. When RAGE binds with one of multiple ligands, its cytoplasmic domain is phosphorylated by PKC $\zeta$. In HEK293 cells, RAGE phosphorylated at Ser391 co-precipitated with TIRAP or MYD88, and these interactions promoted downstream signal mediators, such as NF- $\mathrm{kB}$, AKT, JNK, Rac1, and p38 [151]. Furthermore, in several types of cancer cells, DOCK7 (an $\mathrm{XYZ}$ ) binds to the cytoplasmic domain of RAGE and leads to Cdc42 activation [155].

\section{RAGE in Diseases}

RAGE overexpression and activation are hallmarks of various diseases, including neurodegenerative, cardiovascular, vascular, and coronary diseases and atherosclerosis, diabetes, retinopathy, and cancer [58,159-168]. When a ligand binds to RAGE, downstream signaling pathways, including PI3K, ERK1/2, STAT, JAK, Rho GTPase, and transcription factors (AP-1 and NF- $\mathrm{KB})$, are activated $[15,19,166,169,170]$. Furthermore, RAGE binding can also increase RAGE expression (Figure 3) [50].

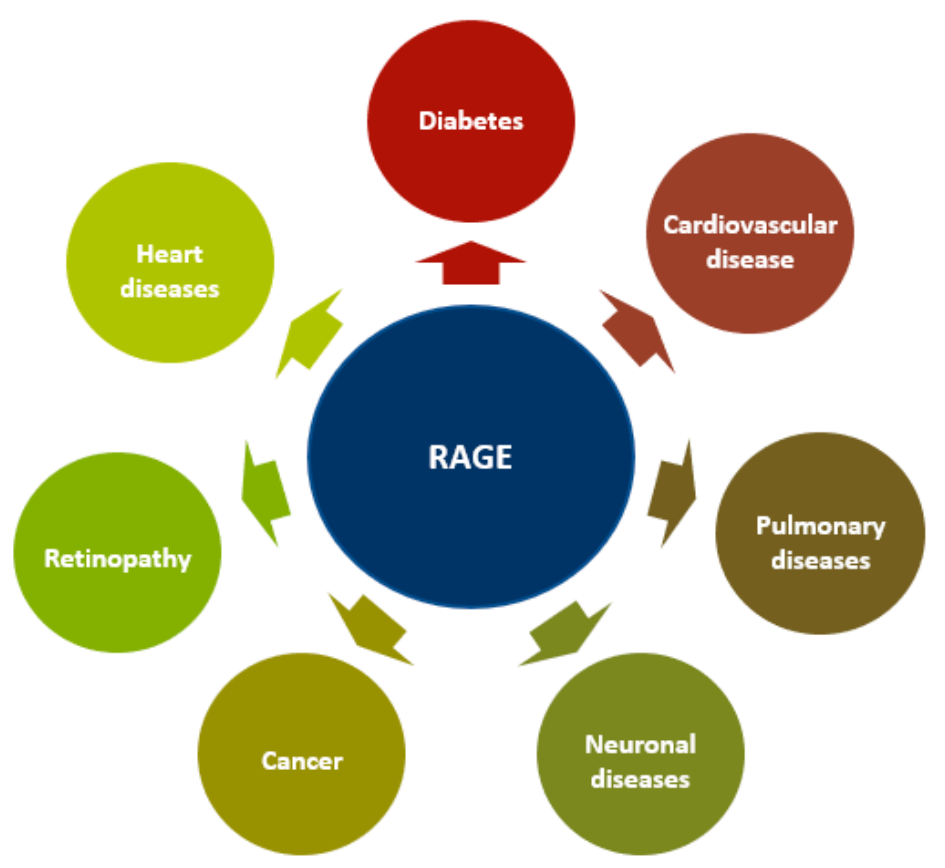

Figure 3. RAGE in different diseases. The overexpression and activation of RAGE are hallmarks of various diseases including neurodegenerative, cardiovascular, pulmonary and heart diseases, atherosclerosis, diabetes, retinopathy, and cancer.

\subsection{Diabetes and Cardiovascular Disease}

RAGE and its ligands accumulate in acute inflammatory conditions, such as diabetes, atherosclerosis, and nondiabetic vascular disease $[58,159,161,171,172]$. Diabetes mellitus is a disease of metabolic dysregulation resulting from defective insulin secretion, insulin resistance, or both. The RAGE-AGE pathway mediates vascular calcification and increases bone matrix protein levels through TGF- $\beta$, ERK1/2, fetuin-A, p38MAPK, PKC, and NF- $\mathrm{BB}$ [173]. AGEs significantly enhanced vascular intracellular calcium levels in rat bovine vascular smooth muscle cells (BVSMCs) [174], and induced cytosolic ROS production, which led to mitochondrial permeability transition and mitochondrial complex I deficiency in rodents [175]. Atherosclerosis is an inflammatory disease of the arterial walls, and RAGE has 
been linked to atherosclerosis development via several ligands, including AGEs, HMGB1, and S100 proteins [161]. Diabetes accelerates atherogenesis and RAGE deletion suppressed atherogenesis in ApoE null mice by activating the TGF- $\beta$ /ROCK1 pathway [176]. Furthermore, AGE-RAGE accumulates in atherosclerotic lesions and increases the protein levels of MCP-1, PAI-1, VCAM-1, and ICAM-1 [177].

\subsection{Neurodegeneration}

RAGE has been reported to be elevated in human brain tissue in neurological disorders, including AD, Huntington's disease, Parkinson's disease, and schizophrenia [166,178-181]. RAGE-mediated transport of circulating $A \beta$ across the BBB leads to $A \beta$ accumulation and disruption of the brain's vascular system [66]. HMGB1/HMGB1 receptors (TLR4 and RAGE) mediate the acute phase, during which damage to ischemic tissue and BBB permeability increase. In contrast, during the final phase of ischemic brain injury, HMGB1 promotes recovery and remodeling [182]. Immunohistochemical studies have demonstrated that RAGE levels are diminished in AD patients and that some of its ligands, such as AGEs, S100, and $A \beta$, lead to RAGE overexpression in neurons, microglia, astrocytes, and BBB vasculature $[166,183-186]$. Furthermore, in microglia, S100B/RAGE upregulated the Rac-1/JNK pathway and the transcriptional factors NF-kB and AP-1 [187].

\subsection{Cancer}

RAGE has been implicated in the pathogeneses of breast, bladder, hepatic, pancreatic, colorectal, gastric, and lung cancer, glioma, and melanoma [62,188-192]. RAGE is associated with various pathophysiological conditions and increased in cell migration and invasion resistance to apoptosis, autophagy stimulation, proliferation, and metastasis. Blocking RAGE signaling diminished tumor growth and proliferation in murine cancer models and offers an attractive means of targeting RAGE-mediated carcinogenesis $[15,62,189,190]$. AGE/RAGE pathways induced pro-tumorigenic proteins, such as ERK1/2 and cREB1 (cAMP response element-binding protein 1), and cancer progression and metastasis by MCF-7 breast cancer cells [193]. RAGE and its ligands also play vital roles in pancreatic ductal adenocarcinoma (PDAC) by increasing NF- $\mathrm{kB}$ activity and may be directly activated RAS which KRAS oncogenic mutations are observed in up to $30 \%$ of all cancers and in PDAC KRAS mutation is in nearly all tumors [194]. Interactions between RAGE and S100 proteins or HMGB1 are involved in melanoma progression and metastasis [195], and the AGE/RAGE pathway was found to increase the phosphorylation of ERK and promote tumor progression, invasion, and metastasis in gastric cancer via the RAGE/ERK/Sp1/MMP2 pathway [196]. HSP70 (heat shock protein 70) is actively released under inflammatory conditions and activates the inflammatory pathway. Somensi et al. demonstrated that HSP70 directly binds RAGE and stimulates ERK1/2, NF- $\mathrm{KB}$, and TNF- $\alpha$ in human lung cancer cells A549 [197]. The AGE/RAGE pathway is also involved in carcinogenesis via RAS/ERK/Rac/CDC43 signaling [198]. PR3-RAGE binding mediates a signal transduction cascade involving the phosphorylations and activations of ERK/2 and JNK1 in prostate cancer cells [199]. Furthermore, elevated expressions of RAGE, thyroid transcription factor 1 (TTF-1), glucose transporter 1 (GLUT-1), and SOX2 were suggested to be early events during the development of $\mathrm{HCV}$ (hepatitis $C$ virus) associated hepatocellular carcinoma (HCC) [200]. RAGE is also involved in the progression of pancreatic cancer in vitro and in vivo via the expressions of MMP2, MMP-9, NF- $\mathrm{kB}$, and vascular endothelial growth factor (VEGF) [201], and in H1975 cells (a non-small cell lung cancer (NSCSLC) cell-line) was found to enhance growth, metastasis, and EMT (epithelial-mesenchymal transition) by activating the P13K/AKT and KRAS/RAF-1 pathways. Furthermore, in a H195 cell xenograft model. RAGE downregulation reduced tumor growth [202]. Thus, RAGE has been determined to be oncogenic and its involvement in diverse cancers has been well demonstrated, which suggests RAGE-ligand interactions offer promising therapeutic targets for RAGE-related diseases. 


\subsection{Other Diseases}

Endothelial dysfunctions involve of the extracellular matrix (ECM) enzymes lysyl oxidase (LOX) and endothelin-1 (ET-1). At the gene level, the expressions of these enzymes are regulated by transcription factors such as NF- $\mathrm{KB}$ and AP-1. In human endothelial cells, AGE/RAGE increased the expressions of LOX and ET-1 through the AGE/RAGE/MAPK signaling cascade, which disrupted endothelial homeostasis by promoting cellular proliferation, altering the biomechanical properties of ECM, and impairing endothelial barrier functions [203]. In addition, uric acid (UA) induces endothelial dysfunction by inhibiting nitric oxide production. Cai et al. reported that human umbilical vein endothelial cells (HUVECs) exposed to high concentrations of UA overexpressed HMGB1, RAGE, NF-kB, and inflammatory cytokines. Furthermore, blocking RAGE significantly suppressed the upregulations of RAGE and HMGB1 [204].

RAGE and its ligands are also involved in coronary artery disease (CAD). sRAGE elevates acute ischemia and acts as a potential biomarker of acute coronary syndrome (ACS) [165]. Moreover, inhibition of RAGE using sRAGE protected against systolic overload-induced heart failure by modulating the AMPK/mTOR and NF- $\mathrm{kB}$ pathways [163].

Retinal microvascular dysfunction is a major component of diabetic retinopathy. RAGE plays a critical role in Müller glial activation and the downstream cytokine production associated with diabetic retinopathy [205]. In mouse models of type 1 and 2 diabetes, administration of sRAGE reduced early retinopathic abnormalities, such as endothelial and pericyte damage, loss of retinal neuronal function, retinal permeability, microgliosis, and inflammatory perturbation [206-208].

Obesity increases the risks of cardiovascular disease, hypertension, diabetes, and cancer. S100A4, S100A8/9, S100A12, and S100B act as DAMPs, activate receptors such as RAGE and TLR-4, and promote macrophage-based inflammation [209]. Furthermore, genetic deficiency of RAGE inhibited high-fat diet-induced weight gain, adipose tissue inflammation, energy expenditure, and insulin resistance [210].

Elevated RAGE expression in lung alveolar epithelial type 1 (AT1) cells may be involved in the proliferation and differentiation of pulmonary epithelial cells [211]. RAGE is expressed most in lung tissue and is an important mediator of diverse lung pathologies, such as pulmonary fibrosis, lung cancer, allergic airway inflammation (AAI), asthma, pneumonia, chronic obstructive pulmonary disease (COPD), bronchopulmonary dysplasia, and cystic fibrosis [168].

\subsection{RAGE Polymorphisms and Inflammatory Disease}

The gene coding for RAGE is located within the gene-dense major histocompatibility class III region on chromosome 6 , which contains numerous genes involved in immune and inflammatory responses [212]. At least 30 polymorphisms within the exon, intron, and gene regulatory regions have been identified, and these polymorphisms affect RAGE expression and RAGE-mediated signals [213]. The major genetic variants of the RAGE gene involve a coding change in the $\mathrm{V}$ domain (Gly82Ser) and two changes in its promoter region (-429T/C and -374T/A) [41]. The gly82Ser isoform of RAGE exhibits enhanced ligand-binding affinity and increases inflammatory mediator levels. Gly82Ser genotypes are associated with elevated levels of serum AGE, serum CRP, plasma TNF- $\alpha$, and urinary 8 -iso- $\mathrm{PGF}_{2 \alpha}$ [214]. The promoter region $-439 \mathrm{~T} / \mathrm{C}$ variant of the RAGE gene acts as a biomarker of the diabetic/pre-diabetic state. In diabetic subjects, the $-429 \mathrm{~T} / \mathrm{C}$ variant was associated with higher hemoglobin $\mathrm{A}_{1 \mathrm{c}}\left(\mathrm{HbA}_{1 \mathrm{C}}\right)$ levels. In addition, the $-374 \mathrm{~T} / \mathrm{A}$ allele has been shown to affect gene transcription and to be a potential marker of vascular disease [215].

Although RAGE is greatly expressed in adult lung tissues, RAGE knockout (RAGE$\mathrm{KO}$ ) mice do not exhibit pulmonary changes associated with life expectancy [216]. However, RAGE-KO mice appear to have an extended life span, as more reached an age of 24 months than did wild-type mice in a comparative study [217]. 
sRAGE administration dose-dependently reduced aortic atherosclerotic lesion sizes, numbers, and complexities [41,218], and in sRAGE suppressed diabetic complications and inflammatory states [219]. Further studies are required to better understand the effects of RAGE isoforms and sRAGE.

\section{RAGE Inhibitors}

Interestingly, RAGE KO mice are healthy and developmentally normal, which suggests RAGE knockdown might be a safe therapeutic strategy [217]. Furthermore, extracellular ligand-based RAGE inhibitors have been shown to be effective in RAGEmediated diseases. RAGE inhibitors are summarized in Table 2. TTP488 (azeliragon, also called PF-04494700; chemical name 3-[4-[2-butyl-1-[4-(4-chlorophenoxy) phenyl]imidazol4-yl]phenoxy]-N,N-diethylpropan-1-amine) is an orally bioavailable small molecule that can cross the BBB [220]. TTP488 binds with multiple ligands, such as AGEs, HMGB1, CML, S100B, and A $\beta[4,220,221]$. TTP488 administration inhibited inflammatory signaling and neuronal $A \beta$ accumulation in a mouse model of AD. While 10 weeks of treatment with TTP488 was found to be safe and well-tolerated in subjects with mild-to-moderate AD, TTP488 did not appear to show consistent effect on plasma levels of A $\beta$ and inflammatory biomarkers [4,220,221]. Structurally, TTP488 presents two hydrophobic moieties, an aliphatic chain, and an electron-deficient aromatic group. TTP488 was developed by modifying the imidazole ring, the hydrophobic side group, and the aromatic core [222,223]. YS Lee et al. reported that a trisubstituted thiazole inhibited RAGE-A $\beta$ interactions [222]. YT Han et al. discovered a novel series of 4,6-disubstituted 2-amino pyrimidines that act as RAGE inhibitors. SPR showed these inhibitors directly bind to RAGE and predicted the binding mode of 4,6-bis(4-chlorophenyl) pyrimidine analogs to the RAGE V-domain. Pyrimidine analogs also A $\beta$-induced NF- $\mathrm{kB}$ signaling in C6 glioma cells [223]. In later studies, a 4-fluorophenoxy analog improved RAGE inhibitory activity more than the parent 2-aminopyrimidine in vitro, and SPR confirmed direct binding between this analog and RAGE. Moreover, a 4-fluorophenoxy analog significantly reduced $A \beta$ entry into the brain [224]. Furthermore, 6-phenoxy-2-phenylbenzoxazole derivatives that inhibit the RAGE- A $\beta$ interaction in vivo and were not toxic to HT22 cells at $10 \mu \mathrm{M}$. These derivatives appeared to block $A \beta$ transport across the BBB but did not seem to affect $A \beta$ or amyloid plaque in the brain [225].

Table 2. RAGE Inhibitors.

\begin{tabular}{|c|c|c|c|}
\hline Inhibitors & Targeting of RAGE Domain & Effects & Ref. \\
\hline TTP488 & $\mathrm{V}$ & $\begin{array}{l}\text { AGEs, HMGB1, CML, S100B, and A } \beta \text {-RAGE } \\
\text { binding inhibition }\end{array}$ & {$[4,220,221]$} \\
\hline $\begin{array}{l}\text { 4,6-disubstituted 2-amino } \\
\text { pyrimidines }\end{array}$ & $\mathrm{V}$ & A $\beta$-RAGE binding inhibition & [223] \\
\hline 4-fluorophenoxy analog & $\mathrm{V}$ & Inhibition of amyloid plaques inside the brain & [224] \\
\hline FPS-ZM1 & $\mathrm{V}$ & $\begin{array}{l}\text { A } \beta \text {-RAGE binding inhibition and low cytotoxicity } \\
\text { in vitro and in vivo }\end{array}$ & [186] \\
\hline GM-1111 & VC1C2 & $\begin{array}{l}\text { CML, GMGB1, and S100B-RAGE binding } \\
\text { inhibition }\end{array}$ & [226] \\
\hline S100-derived peptide & VC1C2 & $\begin{array}{c}\text { Reduced RAGE-mediated activation of NF- } \mathrm{B} \text {, } \\
\text { inflammation, tumor growth, and metastasis in } \\
\text { various cancer cells }\end{array}$ & [227] \\
\hline HMGB1-derived Peptide & VC1C2 & $\begin{array}{l}\text { Suppressed the formation of pulmonary } \\
\text { metastasis and invasion in tumor cells }\end{array}$ & [228] \\
\hline Alagebrium & AGE cross-link breaker & $\begin{array}{l}\text { Reduced AGE accumulation and atherosclerotic } \\
\text { plaque formation and lesions }\end{array}$ & [73] \\
\hline
\end{tabular}


Table 2. Cont.

\begin{tabular}{ccccc}
\hline Inhibitors & Targeting of RAGE Domain & Effects & Ref. \\
\hline DNA-aptamers & cytoplasmic & Inhibition of ctRAGE interaction with mDia1 & [14] \\
\hline Group of 13 compounds & $\mathrm{V}$ & inhibit interaction between RAGE and S100B & [230] \\
\hline Aptamer-based antagonist & $\begin{array}{l}\text { against the AGE-RAGE axis in } \\
\text { AGEs: Advanced glycation end-products; HMGB1: High mobility group box-1 protein; CML: } N_{\mathcal{\varepsilon}} \text {-carboxymethyl-lysine; ctRAGE: }\end{array}$
\end{tabular}

On the other hand, FPS-ZM1 ( $N$-benzyl- $N$-cyclohexyl-4-chlorobenzamide) inhibits the interaction between the RAGE $V$ domain and $A \beta$ and the ability of $A \beta$ to cross the BBB. FPS-ZM1 acts to block RAGE-mediated inflammatory signaling and inhibits nuclear NF- $k B$ levels and BACE1, a key enzyme involved in the generation of $A \beta$ in mouse brains. In addition, FPS-ZM1 had no toxic side effects in mice at doses up to $500 \mathrm{mg} / \mathrm{kg}$ [186]. Interestingly, treatment with FPS-ZM1 for 8 weeks attenuated cardiac remodeling and dysfunction in mice subjected to transverse aortic constriction (TAC), and treatment of TAC mice with FPS-ZM1 enhanced AMPK phosphorylation and reduced the phosphorylations of mTOR and NF- $\mathrm{kB}$ in cardiac tissues. In addition, treatment of TAC mice with FPSZM1 diminished endoplasmic reticulum stress, oxidative stress, and inflammation in cardiac tissues [163]. In a mouse model of toluene diisocyanate-induced asthma, FPS-ZM1 attenuated airway inflammation and $\beta$-catenin signaling [231], and in another study, FPSZM1 impaired primary tumor growth, prevented tumor angiogenesis and inflammatory cell recruitment, and most importantly, inhibited metastasis to the lungs and liver [190].

Chondroitin sulfate and heparan sulfate strongly bind to RAGE and suppressed the colonization of lungs by tumor cells [232], and GM-1111 inhibited interactions between RAGE and CML, HMGB1, and S100B and exhibited anti-inflammatory activity [226]. S100derived peptide (ELKVLMEKEL) was found to compete for the RAGE site required for binding ligands, such as S100P, S100A4, and HMGB1, and reduced RAGE-mediated NF- $\mathrm{kB}$ activation, inflammation, tumor growth, and metastasis in different cancer cells [227]. In addition, peptides derived from the COOH-terminal motif of HMGB1 (150-183, 162177, 160-183) also bind RAGE, inhibit the interaction between RAGE and HMGB1, and effectively suppressed the pulmonary metastasis and invasion of tumor cells [228].

Alagebrium (ALT7-11) is an AGE cross-link breaker, and treatment with alagebrium reduced AGE accumulation and atherosclerotic plaque formation and lesions [73]. AGERAGE signaling contributes to the development and progression of various diabetes and aging-related disorders. Yamagishi et al. found that DNA-aptamers might provide a potential treatment for vascular complications of diabetes and cancer by targeting the AGE-RAGE axis [229].

The intracellular domain of RAGE is required for many types of RAGE signals and for inducing downstream effects, and the disruption of RAGE-mDia1 binding is important for the therapeutic targeting of RAGE-mediated chronic inflammatory diseases. In one study, 13 compounds with high affinity for the cytoplasmic domain of RAGE (ctRAGE) inhibited the interaction between ctRAGE and mDia1 [14].

Recently found is that Src homology 2 domain-containing leukocyte protein of $76 \mathrm{kDa}$ (SLP76) interacts with a cytosolic tail of RAGE, resulting in prompt activation of downstream signaling and gene transcription of pro-inflammatory mediators, such as TNF, CXCL10, HMGB1, and IL-6 in HEK 293 cells. Therapeutic targeting of interaction SLP76 with RAGE as a new approach for lethal sepsis [233].

Zheng et al. reported that aptamer-based antagonist against RAGE inhibits tumor growth and microvasculature formation in colorectal tumor mice by suppression of the RAGE/NF-kB/VEGF-A signaling [230]. 


\section{Conclusions}

RAGE is a multi-ligand receptor of the immunoglobulin family. RAGE and its ligands are present on most cell types and are involved in diabetes, diabetes complications, chronic inflammation, neurodegenerative disorders, and cancer. Recent advances have revealed the enormous breadth of the influence of RAGE and its ligands. Although, sRAGE and esRAGE act as biomarkers and endogenous protection factors against RAGE-mediated pathologies, sRAGE and esRAGE may not be ideal therapeutic means for targeting RAGE because they are large recombinant proteins that are difficult to produce at therapeutic levels. Accordingly, small-molecular inhibitors have been developed to target the extracellular ligand-binding site of RAGE and its intracellular signaling pathway. Further, there are critical issues that remain to be addressed of the understanding of RAGE-targeting therapy and the long-term impact of RAGE blockade in humans. Future investigations are required to improve understanding of the characteristics of efficient RAGE inhibitors to develop a significant understanding of the impact of RAGE blockage.

Author Contributions: H.J.K. wrote the manuscript. M.S.J. and S.B.J. designed and analysis of the manuscript. All authors have read and agreed to the published version of the manuscript.

Funding: This research was funded by MEST (2018R1D1A1B07043701) to S.B.J and (2016R1D1A1B02011142) to M.S.J.

Acknowledgments: This study was supported by the Basic Science Research Program through the National Research Foundation of Korea (NRF) funded by the Ministry of Education, Science and Technology (Grant no. 2018R1D1A1B07043701 to S.B.J and 2016R1D1A1B02011142 to M.S.J.).

Conflicts of Interest: The authors declare no conflict of interest.

\section{References}

1. Neeper, M.; Schmidt, A.; Brett, J.; Yan, S.; Wang, F.; Pan, Y.; Elliston, K.; Stern, D.; Shaw, A. Cloning and expression of a cell surface receptor for advanced glycosylation end products of proteins. J. Biol. Chem. 1992, 267, 14998-15004. [CrossRef]

2. Leclerc, E.; Fritz, G.; Vetter, S.W.; Heizmann, C.W. Binding of S100 proteins to RAGE: An update. Biochim. Biophys. Acta (BBA)-Bioenerg. 2009, 1793, 993-1007. [CrossRef]

3. Hori, O.; Brett, J.; Slattery, T.; Cao, R.; Zhang, J.; Chen, J.X.; Nagashima, M.; Lundh, E.R.; Vijay, S.; Nitecki, D.; et al. The receptor for advanced glycation end products (RAGE) is a cellular binding site for amphoterin: Mediation of neurite outgrowth and co-expression of rage and amphoterin in the developing nervous system. J. Biol. Chem. 1995, 270, 25752-25761. [CrossRef]

4. Galasko, D.; Bell, J.; Mancuso, J.Y.; Kupiec, J.W.; Sabbagh, M.N.; van Dyck, C.; Thomas, R.G.; Aisen, P.S.; Alzheimer's Disease Cooperative Study. Clinical trial of an inhibitor of RAGE-A $\beta$ interactions in Alzheimer disease. Neurology 2014, 82, 1536-1542. [CrossRef]

5. Yan, S.D.; Chen, X.; Fu, J.; Chen, M.; Zhu, H.; Roher, A.; Slattery, T.; Zhao, L.; Nagashima, M.; Morser, J. RAGE and amyloid- $\beta$ peptide neurotoxicity in Alzheimer's disease. Nature 1996, 382, 685-691. [CrossRef]

6. Serratos, I.N.; Castellanos, P.; Pastor, N.; Millán-Pacheco, C.; Rembao, D.; Pérez-Montfort, R.; Cabrera, N.; Reyes-Espinosa, F.; Díaz-Garrido, P.; López-Macay, A. Modeling the interaction between quinolinate and the receptor for advanced glycation end products (RAGE): Relevance for early neuropathological processes. PLoS ONE 2015, 10, e0120221. [CrossRef] [PubMed]

7. Hudson, B.I.; Lippman, M.E. Targeting RAGE Signaling in Inflammatory Disease. Annu. Rev. Med. 2018, 69, 349-364. [CrossRef] [PubMed]

8. Sirois, C.M.; Jin, T.; Miller, A.L.; Bertheloot, D.; Nakamura, H.; Horvath, G.L.; Mian, A.; Jiang, J.; Schrum, J.; Bossaller, L.; et al. RAGE is a nucleic acid receptor that promotes inflammatory responses to DNA. J. Exp. Med. 2013, 210, 2447-2463. [CrossRef]

9. Andersson, U.; Erlandsson-Harris, H.; Yang, H.; Tracey, K.J. HMGB1 as a DNA-binding cytokine. J. Leukoc. Biol. 2002, 72, 1084-1091.

10. Yamamoto, Y.; Harashima, A.; Saito, H.; Tsuneyama, K.; Munesue, S.; Motoyoshi, S.; Han, D.; Watanabe, T.; Asano, M.; Takasawa, S. Septic shock is associated with receptor for advanced glycation end products ligation of LPS. J. Immunol. 2011, 186, 3248-3257. [CrossRef]

11. Tian, J.; Huang, K.; Krishnan, S.; Svabek, C.; Rowe, D.C.; Brewah, Y.; Sanjuan, M.; Patera, A.C.; Kolbeck, R.; Herbst, R.; et al. RAGE inhibits human respiratory syncytial virus syncytium formation by interfering with F-protein function. J. Gen. Virol. 2013, 94, 1691-1700. [CrossRef]

12. Anisuzzaman, A.; Hatta, T.; Miyoshi, T.; Matsubayashi, M.; Islam, M.K.; Alim, M.A.; Abu Anas, M.; Hasan, M.M.; Matsumoto, Y.; Yamamoto, Y.; et al. Longistatin in tick saliva blocks advanced glycation end-product receptor activation. J. Clin. Investig. 2014, 124, 4429-4444. [CrossRef] 
13. Rai, V.; Maldonado, A.Y.; Burz, D.S.; Reverdatto, S.; Schmidt, A.M.; Shekhtman, A. Signal Transduction in Receptor for Advanced Glycation End Products (RAGE). J. Biol. Chem. 2012, 287, 5133-5144. [CrossRef]

14. Manigrasso, M.B.; Pan, J.; Rai, V.; Zhang, J.; Reverdatto, S.; Quadri, N.; DeVita, R.J.; Ramasamy, R.; Shekhtman, A.; Schmidt, A.M. Small Molecule Inhibition of Ligand-Stimulated RAGE-DIAPH1 Signal Transduction. Sci. Rep. 2016, 6, 22450. [CrossRef]

15. Hudson, B.I.; Kalea, A.Z.; Arriero, M.d.; Harja, E.; Boulanger, E.; D'Agati, V.; Schmidt, A.M. Interaction of the RAGE cytoplasmic domain with diaphanous-1 is required for ligand-stimulated cellular migration through activation of Rac1 and Cdc. J. Biol. Chem. 2008, 283, 34457-34468. [CrossRef]

16. Ishihara, K.; Tsutsumi, K.; Kawane, S.; Nakajima, M.; Kasaoka, T. The receptor for advanced glycation end-products (RAGE) directly binds to ERK by a D-domain-like docking site. FEBS Lett. 2003, 550, 107-113. [CrossRef]

17. Koch, M.; Chitayat, S.; Dattilo, B.M.; Schiefner, A.; Diez, J.; Chazin, W.J.; Fritz, G. Structural Basis for Ligand Recognition and Activation of RAGE. Structures 2010, 18, 1342-1352. [CrossRef] [PubMed]

18. Lander, H.M.; Tauras, J.M.; Ogiste, J.S.; Hori, O.; Moss, R.A.; Schmidt, A.M. Activation of the receptor for advanced glycation end products triggers a p21 ras-dependent mitogen-activated protein kinase pathway regulated by oxidant stress. J. Biol. Chem. 1997, 272, 17810-17814. [CrossRef]

19. Huang, J.-S.; Guh, J.-Y.; Chen, H.-C.; Hung, W.-C.; Lai, Y.-H.; Chuang, L.-Y. Role of receptor for advanced glycation end-product (RAGE) and the JAK/STAT-signaling pathway in AGE-induced collagen production in NRK-49F cells. J. Cell. Biochem. 2001, 81, 102-113. [CrossRef]

20. Goldin, A.; Beckman, J.A.; Schmidt, A.M.; Creager, M.A. Advanced glycation end products: Sparking the development of diabetic vascular injury. Circulation 2006, 114, 597-605. [CrossRef] [PubMed]

21. Nenna, A.; Spadaccio, C.; Lusini, M.; Ulianich, L.; Chello, M.; Nappi, F. Basic and Clinical Research Against Advanced Glycation End Products (AGEs): New Compounds to Tackle Cardiovascular Disease and Diabetic Complications. Recent Pat. Cardiovasc. Drug Discov. 2016, 10, 10-33. [CrossRef] [PubMed]

22. Santilli, F.; Vazzana, N.; Bucciarelli, L.G.; Davì, G. Soluble forms of RAGE in human diseases: Clinical and therapeutical implications. Curr. Med. Chem. 2009, 16, 940-952. [CrossRef] [PubMed]

23. Bierhaus, A.; Schiekofer, S.; Schwaninger, M.; Andrassy, M.; Humpert, P.M.; Chen, J.; Hong, M.; Luther, T.; Henle, T.; Klöting, I.; et al. Diabetes-associated sustained activation of the transcription factor nuclear factor-КB. Diabetes 2001, 50, 2792-2808. [CrossRef] [PubMed]

24. Soro-Paavonen, A.; Watson, A.M.D.; Li, J.; Paavonen, K.; Koitka, A.; Calkin, A.C.; Barit, D.; Coughlan, M.T.; Drew, B.G.; Lancaster, G.I.; et al. Receptor for Advanced Glycation End Products (RAGE) Deficiency Attenuates the Development of Atherosclerosis in Diabetes. Diabetes 2008, 57, 2461-2469. [CrossRef]

25. Chavakis, T.; Bierhaus, A.; Nawroth, P.P. RAGE (receptor for advanced glycation end products): A central player in the inflammatory response. Microbes Infect. 2004, 6, 1219-1225. [CrossRef]

26. Turovskaya, O.; Foell, D.; Sinha, P.; Vogl, T.; Newlin, R.; Nayak, J.; Nguyen, M.; Olsson, A.; Nawroth, P.P.; Bierhaus, A.; et al. RAGE, carboxylated glycans and S100A8/A9 play essential roles in colitis-associated carcinogenesis. Carcinogenesis 2008, 29, 2035-2043. [CrossRef]

27. Bongarzone, S.; Savickas, V.; Luzi, F.; Gee, A.D. Targeting the Receptor for Advanced Glycation Endproducts (RAGE): A Medicinal Chemistry Perspective. J. Med. Chem. 2017, 60, 7213-7232. [CrossRef]

28. Xue, J.; Rai, V.; Singer, D.; Chabierski, S.; Xie, J.; Reverdatto, S.; Burz, D.S.; Schmidt, A.M.; Hoffmann, R.; Shekhtman, A. Advanced Glycation End Product Recognition by the Receptor for AGEs. Structures 2011, 19, 722-732. [CrossRef]

29. Hudson, B.I.; Carter, A.M.; Harja, E.; Kalea, A.Z.; Arriero, M.; Yang, H.; Grant, P.J.; Schmidt, A.M. Identification, classification, and expression of RAGE gene splice variants. FASEB J. 2007, 22, 1572-1580. [CrossRef]

30. Xu, D.; Young, J.H.; Krahn, J.M.; Song, D.; Corbett, K.D.; Chazin, W.J.; Pedersen, L.C.; Esko, J.D. Stable RAGE-Heparan Sulfate Complexes Are Essential for Signal Transduction. ACS Chem. Biol. 2013, 8, 1611-1620. [CrossRef]

31. Xie, J.; Burz, D.S.; He, W.; Bronstein, I.B.; Lednev, I.; Shekhtman, A. Hexameric Calgranulin C (S100A12) Binds to the Receptor for Advanced Glycated End Products (RAGE) Using Symmetric Hydrophobic Target-binding Patches. J. Biol. Chem. 2007, 282, 4218-4231. [CrossRef]

32. Wei, W.; Lampe, L.; Park, S.; Vangara, B.S.; Waldo, G.S.; Cabantous, S.; Subaran, S.S.; Yang, N.; Lakatta, E.; Lin, L. Disulfide Bonds within the C2 Domain of RAGE Play Key Roles in Its Dimerization and Biogenesis. PLoS ONE 2012, 7, e50736. [CrossRef]

33. Russ, W.P.; Engelman, D.M. The GxxxG motif: A framework for transmembrane helix-helix association. J. Mol. Biol. 2000, 296, 911-919. [CrossRef]

34. Huttunen, H.J.; Fages, C.; Rauvala, H. Receptor for advanced glycation end products (RAGE)-mediated neurite outgrowth and activation of NF- $\mathrm{kB}$ require the cytoplasmic domain of the receptor but different downstream signaling pathways. J. Biol. Chem. 1999, 274, 19919-19924. [CrossRef]

35. Harja, E.; Bu, D.-X.; Hudson, B.; Chang, J.S.; Shen, X.; Hallam, K.; Kalea, A.Z.; Lu, Y.; Rosario, R.H.; Oruganti, S.; et al. Vascular and inflammatory stresses mediate atherosclerosis via RAGE and its ligands in apoE-/- mice. J. Clin. Investig. 2008, 118, 183-194. [CrossRef]

36. Grossin, N.; Boulanger, E.; Wautier, M.-P.; Wautier, J.-L. The different isoforms of the receptor for advanced glycation end products are modulated by pharmacological agents. Clin. Hemorheol. Microcirc. 2010, 45, 143-153. [CrossRef] [PubMed] 
37. Pan, H.; He, L.; Wang, B.; Niu, W. The relationship between RAGE gene four common polymorphisms and breast cancer risk in northeastern Han Chinese. Sci. Rep. 2015, 4, 4355. [CrossRef] [PubMed]

38. Cai, W.; Li, J.; Xu, J.-X.; Liu, Y.; Zhang, W.; Xiao, J.-R.; Zhu, L.-Y.; Liu, J.-Y. Association of 2184AG Polymorphism in the RAGE Gene with Diabetic Nephropathy in Chinese Patients with Type 2 Diabetes. J. Diabetes Res. 2015, 2015, 1-6. [CrossRef] [PubMed]

39. Yonekura, H.; Yamamoto, Y.; Sakurai, S.; Petrova, R.G.; Abedin, J.; Li, H.; Yasui, K.; Takeuchi, M.; Makita, Z.; Takasawa, S.; et al Novel splice variants of the receptor for advanced glycation end-products expressed in human vascular endothelial cells and pericytes, and their putative roles in diabetes-induced vascular injury. Biochem. J. 2003, 370, 1097-1109. [CrossRef]

40. Zong, H.; Ward, M.; Stitt, A.W. AGEs, RAGE, and diabetic retinopathy. Curr. Diabetes Rep. 2011, 11, 244-252. [CrossRef] [PubMed]

41. Kalea, A.Z.; Schmidt, A.M.; Hudson, B.I. RAGE: A novel biological and genetic marker for vascular disease. Clin. Sci. 2009, 116, 621-637. [CrossRef] [PubMed]

42. Prasad, K. Is there any evidence that AGE/sRAGE is a universal biomarker/risk marker for diseases? Mol. Cell. Biochem. 2019, 451, 139-144. [CrossRef] [PubMed]

43. Hamasaki, M.Y.; Barbeiro, H.V.; De Souza, H.P.; Machado, M.C.C.; Da Silva, F.P. sRAGE in septic shock: A potential biomarker of mortality. Rev. Bras. Ter. Intensiv. 2014, 26, 392-396. [CrossRef]

44. Hofmann, M.A.; Drury, S.; Fu, C.; Qu, W.; Taguchi, A.; Lu, Y.; Avila, C.; Kambham, N.; Bierhaus, A.; Nawroth, P.; et al. RAGE Mediates a Novel Proinflammatory Axis: A Central Cell Surface Receptor for S100/Calgranulin Polypeptides. Cell 1999, 97, 889-901. [CrossRef]

45. Chavakis, T.; Bierhaus, A.; Al-Fakhri, N.; Schneider, D.; Witte, S.; Linn, T.; Nagashima, M.; Morser, J.; Arnold, B.; Preissner, K.T. The pattern recognition receptor (RAGE) is a counterreceptor for leukocyte Integrins a novel pathway for inflammatory cell recruitment. J. Exp. Med. 2003, 198, 1507-1515. [CrossRef]

46. Schmidt, A.M.; Du Yan, S.; Stern, D.M. The biology of the receptor for advanced glycation end products and its ligands. Biochim. Biophys. Acta (BBA)-Bioenerg. 2000, 1498, 99-111. [CrossRef]

47. Orlova, V.V.; Choi, E.Y.; Xie, C.; Chavakis, E.; Bierhaus, A.; Ihanus, E.; Ballantyne, C.M.; Gahmberg, C.; Bianchi, M.E.; Nawroth, P.P.; et al. A novel pathway of HMGB1-mediated inflammatory cell recruitment that requires Mac-1-integrin. EMBO J. 2007, 26, 1129-1139. [CrossRef] [PubMed]

48. Xie, J.; Reverdatto, S.; Frolov, A.; Hoffmann, R.; Burz, D.S.; Shekhtman, A. Structural Basis for Pattern Recognition by the Receptor for Advanced Glycation End Products (RAGE). J. Biol. Chem. 2008, 283, 27255-27269. [CrossRef]

49. Ibrahim, Z.A.; Armour, C.; Phipps, S.; Sukkar, M. RAGE and TLRs: Relatives, friends or neighbours? Mol. Immunol. 2013, 56, 739-744. [CrossRef] [PubMed]

50. Fritz, G. RAGE: A single receptor fits multiple ligands. Trends Biochem. Sci. 2011, 36, 625-632. [CrossRef]

51. Kierdorf, K.; Fritz, G. RAGE regulation and signaling in inflammation and beyond. J. Leukoc. Biol. 2013, 94, 55-68. [CrossRef] [PubMed]

52. Han, S.-H.; Kim, Y.H.; Mook-Jung, I. RAGE: The beneficial and deleterious effects by diverse mechanisms of actions. Mol. Cells 2011, 31, 91-97. [CrossRef]

53. Kaneko, M.; Bucciarelli, L.; Hwang, Y.C.; Lee, L.; Yan, S.F.; Schmidt, A.M.; Ramasamy, R. Aldose Reductase and AGE-RAGE Pathways: Key Players in Myocardial Ischemic Injury. Ann. N. Y. Acad. Sci. 2005, 1043, 702-709. [CrossRef]

54. Vincent, A.M.; Perrone, L.; Sullivan, K.A.; Backus, C.; Sastry, A.M.; Lastoskie, C.; Feldman, E.L. Receptor for Advanced Glycation End Products Activation Injures Primary Sensory Neurons via Oxidative Stress. Endocrinology 2007, 148, 548-558. [CrossRef]

55. Wendt, T.; Tanji, N.; Guo, J.; Hudson, B.; Bierhaus, A.; Ramasamy, R.; Arnold, B.; Nawroth, P.P.; Yan, S.F.; D'Agati, V.; et al. Glucose, Glycation, and RAGE: Implications for Amplification of Cellular Dysfunction in Diabetic Nephropathy. J. Am. Soc. Nephrol. 2003, 14, 1383-1395. [CrossRef] [PubMed]

56. Schmidt, A.M.; Yan, S.D.; Wautier, J.-L.; Stern, D. Activation of receptor for advanced glycation end products: A mechanism for chronic vascular dysfunction in diabetic vasculopathy and atherosclerosis. Circ. Res. 1999, 84, 489-497. [CrossRef]

57. Basta, G. Receptor for advanced glycation endproducts and atherosclerosis: From basic mechanisms to clinical implications. Atherosclerosis 2008, 196, 9-21. [CrossRef] [PubMed]

58. Tanji, N.; Markowitz, G.S.; Fu, C.; Kislinger, T.; Taguchi, A.; Pischetsrieder, M.; Stern, D.; Schmidt, A.M.; D'Agati, V.D. Expression of Advanced Glycation End Products and Their Cellular Receptor RAGE in Diabetic Nephropathy and Nondiabetic Renal Disease. J. Am. Soc. Nephrol. 2000, 11, 1656-1666. [CrossRef] [PubMed]

59. Hofmann, M.A.; Drury, S.; Hudson, B.; Gleason, M.R.; Qu, W.; Lu, Y.; Lalla, E.; Chitnis, S.; Monteiro, J.; Stickland, M.H.; et al RAGE and arthritis: The G82S polymorphism amplifies the inflammatory response. Genes Immun. 2002, 3, 123-135. [CrossRef]

60. Schmidt, A.M.; Yan, S.D.; Yan, S.F.; Stern, D.M. The multiligand receptor RAGE as a progression factor amplifying immune and inflammatory responses. J. Clin. Investig. 2001, 108, 949-955. [CrossRef] [PubMed]

61. Rong, L.L.; Gooch, C.; Szabolcs, M.; Herold, K.C.; Lalla, E.; Hays, A.P.; Yan, S.F.; Du Yan, S.S.; Schmidt, A.M. RAGE: A journey from the complications of diabetes to disorders of the nervous system-striking a fine balance between injury and repair. Restor. Neurol. Neurosci. 2005, 23, 355-365. [PubMed]

62. Taguchi, A.; Blood, D.C.; Del Toro, G.; Canet, A.; Lee, D.C.; Qu, W.; Tanji, N.; Lu, Y.; Lalla, E.; Fu, C.; et al. Blockade of RAGE-amphoterin signalling suppresses tumour growth and metastases. Nat. Cell Biol. 2000, 405, 354-360. [CrossRef]

63. Ramasamy, R.; Vannucci, S.J.; Du Yan, S.S.; Herold, K.; Yan, S.F.; Schmidt, A.M. Advanced glycation end products and RAGE: A common thread in aging, diabetes, neurodegeneration, and inflammation. Glycobiology 2005, 15, 16R-28R. [CrossRef] [PubMed] 
64. Pinto, S.S.; Gottfried, C.; Mendez, A.; Gonçalves, D.; Karl, J.; Gonçalves, C.A.; Wofchuk, S.; Rodnight, R. Immunocontent and secretion of S100B in astrocyte cultures from different brain regions in relation to morphology. FEBS Lett. 2000, 486, $203-207$. [CrossRef]

65. Dong, X.D.; Ito, N.; Lotze, M.T.; DeMarco, R.A.; Popovic, P.; Shand, S.H.; Watkins, S.; Winikoff, S.; Brown, C.K.; Bartlett, D.L.; et al. High Mobility Group Box I (HMGB1) Release From Tumor Cells After Treatment: Implications for Development of Targeted Chemoimmunotherapy. J. Immunother. 2007, 30, 596-606. [CrossRef] [PubMed]

66. Deane, R.; Du Yan, S.; Submamaryan, R.K.; LaRue, B.; Jovanovic, S.; Hogg, E.; Welch, D.; Manness, L.; Lin, C.; Yu, J.; et al. RAGE mediates amyloid- $\beta$ peptide transport across the blood-brain barrier and accumulation in brain. Nat. Med. 2003, 9, 907-913. [CrossRef] [PubMed]

67. Lugo-Huitrón, R.; Muñiz, P.U.; Pineda, B.; Pedraza-Chaverrí, J.; Ríos, C.; La Cruz, V.P.-D. Quinolinic Acid: An Endogenous Neurotoxin with Multiple Targets. Oxidative Med. Cell. Longev. 2013, 2013, 1-14. [CrossRef] [PubMed]

68. Rai, V.; Touré, F.; Chitayat, S.; Pei, R.; Song, F.; Li, Q.; Zhang, J.; Rosario, R.; Ramasamy, R.; Chazin, W.J. Lysophosphatidic acid targets vascular and oncogenic pathways via RAGE signaling. J. Exp. Med. 2012, 209, 2339-2350. [CrossRef]

69. He, M.; Kubo, H.; Morimoto, K.; Fujino, N.; Suzuki, T.; Takahashi, T.; Yamada, M.; Yamaya, M.; Maekawa, T.; Yamamoto, Y.; et al. Receptor for advanced glycation end products binds to phosphatidylserine and assists in the clearance of apoptotic cells. EMBO Rep. 2011, 12, 358-364. [CrossRef]

70. Ma, W.; Rai, V.; Hudson, B.I.; Song, F.; Schmidt, A.M.; Barile, G.R. RAGE binds C1q and enhances C1q-mediated phagocytosis. Cell. Immunol. 2012, 274, 72-82. [CrossRef]

71. Semba, R.D.; Najjar, S.S.; Sun, K.; Lakatta, E.G.; Ferrucci, L. Serum carboxymethyl-lysine, an advanced glycation end product, is associated with increased aortic pulse wave velocity in adults. Am. J. Hypertens. 2009, 22, 74-79. [CrossRef]

72. Kellow, N.; Coughlan, M.T. Effect of diet-derived advanced glycation end products on inflammation. Nutr. Rev. 2015, 73, 737-759. [CrossRef] [PubMed]

73. Senatus, L.M.; Schmidt, A.M. The AGE-RAGE Axis: Implications for Age-Associated Arterial Diseases. Front. Genet. 2017, 8, 187. [CrossRef] [PubMed]

74. Xue, J.; Ray, R.; Singer, D.; Böhme, D.; Burz, D.S.; Rai, V.; Hoffmann, R.; Shekhtman, A. The Receptor for Advanced Glycation End Products (RAGE) Specifically Recognizes Methylglyoxal-Derived AGEs. Biochemistry 2014, 53, 3327-3335. [CrossRef] [PubMed]

75. Schäfer, B.W.; Wicki, R.; Engelkamp, D.; Mattei, M.-G.; Heizmann, C.W. Isolation of a YAC clone covering a cluster of nine S100 genes on human chromosome 1q21: Rationale for a new nomenclature of the S100 calcium-binding protein family. Genomics 1995, 25, 638-643. [CrossRef]

76. Steiner, J.; Bernstein, H.-G.; Bogerts, B.; Gos, T.; Richter-Landsberg, C.; Wunderlich, M.; Keilhoff, G. S100B is expressed in, and released from, OLN-93 oligodendrocytes: Influence of serum and glucose deprivation. Neuroscience 2008, 154, 496-503. [CrossRef]

77. Baudier, J.; Glasser, N.; Gerard, D. Ions binding to S100 proteins. I. Calcium- and zinc-binding properties of bovine brain S100 alpha alpha, S100a (alpha beta), and S100b (beta beta) protein: $\mathrm{Zn}^{2+}$ regulates $\mathrm{Ca}^{2+}$ binding on S100b protein. J. Biol. Chem. 1986, 261, 8192-8203. [CrossRef]

78. Leclerc, E.; Fritz, G.; Weibel, M.; Heizmann, C.W.; Galichet, A. S100B and S100A6 Differentially Modulate Cell Survival by Interacting with Distinct RAGE (Receptor for Advanced Glycation End Products) Immunoglobulin Domains. J. Biol. Chem. 2007, 282, 31317-31331. [CrossRef]

79. Rothermundt, M.; Peters, M.; Prehn, J.H.; Arolt, V. S100B in brain damage and neurodegeneration. Microsc. Res. Tech. 2003, 60, 614-632. [CrossRef] [PubMed]

80. Sinha, P.; Okoro, C.; Foell, D.; Freeze, H.; Ostrand-Rosenberg, S.; Srikrishna, G. Proinflammatory S100 Proteins Regulate the Accumulation of Myeloid-Derived Suppressor Cells. J. Immunol. 2008, 181, 4666-4675. [CrossRef]

81. Zimmer, D.B.; Chaplin, J.; Baldwin, A.; Rast, M. S100-mediated signal transduction in the nervous system and neurological diseases. Cell. Mol. Boil. 2005, 51, 201-214.

82. Huttunen, H.J.; Kuja-Panula, J.; Sorci, G.; Agneletti, A.L.; Donato, R.; Rauvala, H. Coregulation of Neurite Outgrowth and Cell Survival by Amphoterin and S100 Proteins through Receptor for Advanced Glycation End Products (RAGE) Activation. J. Biol. Chem. 2000, 275, 40096-40105. [CrossRef]

83. Mueller, A.; Schäfer, B.W.; Ferrari, S.; Weibel, M.; Makek, M.; Höchli, M.; Heizmann, C.W. The Calcium-binding Protein S100A2 Interacts with p53 and Modulates Its Transcriptional Activity. J. Biol. Chem. 2005, 280, 29186-29193. [CrossRef] [PubMed]

84. Maelandsmo, G.M.; Flørenes, V.A.; Mellingsaeter, T.; Hovig, E.; Kerbel, R.S.; Fodstad, Ø. Differential expression patterns of S100A2, S100A4 and S100A6 during progression of human malignant melanoma. Int. J. Cancer 1997, 74, 464-469. [CrossRef]

85. Gupta, S.; Hussain, T.; MacLennan, G.T.; Fu, P.; Patel, J.; Mukhtar, H. Differential Expression of S100A2 and S100A4 During Progression of Human Prostate Adenocarcinoma. J. Clin. Oncol. 2003, 21, 106-112. [CrossRef] [PubMed]

86. Suzuki, F.; Oridate, N.; Homma, A.; Nakamaru, Y.; Nagahashi, T.; Yagi, K.; Yamaguchi, S.; Furuta, Y.; Fukuda, S. S100A2 expression as a predictive marker for late cervical metastasis in stage I and II invasive squamous cell carcinoma of the oral cavity. Oncol. Rep. 2005, 14, 1493-1498. [CrossRef]

87. Feng, G.; Xu, X.; Youssef, E.M.; Lotan, R. Diminished expression of S100A2, a putative tumor suppressor, at early stage of human lung carcinogenesis. Cancer Res. 2001, 61, 7999-8004. 
88. Lee, S.W.; Tomasetto, C.; Swisshelm, K.; Keyomarsi, K.; Sager, R. Down-regulation of a member of the S100 gene family in mammary carcinoma cells and reexpression by azadeoxycytidine treatment. Proc. Natl. Acad. Sci. USA 1992, 89, 2504-2508. [CrossRef]

89. Imazawa, M.; Hibi, K.; Fujitake, S.-I.; Kodera, Y.; Ito, K.; Akiyama, S.; Nakao, A. S100A2 overexpression is frequently observed in esophageal squamous cell carcinoma. Anticancer. Res. 2005, 25, 1247-1250.

90. Smith, S.L.; Gugger, M.; Hoban, P.; Ratschiller, D.; Watson, S.G.; Field, J.K.; Betticher, D.C.; Heighway, J. S100A2 is strongly expressed in airway basal cells, preneoplastic bronchial lesions and primary non-small cell lung carcinomas. Br. J. Cancer 2004, 91, 1515-1524. [CrossRef]

91. El-Rifai, W.; Moskaluk, C.A.; Abdrabbo, M.K.; Harper, J.; Yoshida, C.; Riggins, G.J.; Frierson, H.F.; Powell, S.M. Gastric cancers overexpress S100A calcium-binding proteins. Cancer Res. 2002, 62, 6823-6826.

92. Hough, C.D.; Cho, K.R.; Zonderman, A.B.; Schwartz, D.R.; Morin, P.J. Coordinately up-regulated genes in ovarian cancer. Cancer Res. 2001, 61, 3869-3876. [PubMed]

93. Yammani, R.R.; Carlson, C.S.; Bresnick, A.R.; Loeser, R.F. Increase in production of matrix metalloproteinase 13 by human articular chondrocytes due to stimulation with S100A4: Role of the receptor for advanced glycation end products. Arthritis Rheum. 2006, 54, 2901-2911. [CrossRef] [PubMed]

94. Camby, I.; Lefranc, F.; Titeca, G.; Neuci, S.; Fastrez, M.; Dedecken, L.; Schäfer, B.W.; Brotchi, J.; Heizmann, C.W.; Pochet, R.; et al. Differential expression of S100 calcium-binding proteins characterizes distinct clinical entities in both WHO grade II and III astrocytic tumours. Neuropathol. Appl. Neurobiol. 2000, 26, 76-90. [CrossRef] [PubMed]

95. Kuźnicki, J.; Filipek, A.; Hunziker, P.E.; Huber, S.; Heizmann, C.W. Calcium-binding protein from mouse Ehrlich ascites-tumour cells is homologous to human calcyclin. Biochem. J. 1989, 263, 951-956. [CrossRef]

96. Kuźnicki, J.; Filipek, A.; Heimann, P.; Kaczmarek, L.; Kamińska, B. Tissue specific distribution of calcyclin-10.5 kDa Ca ${ }^{2+}$-binding protein. FEBS Lett. 1989, 254, 141-144. [CrossRef]

97. Stradal, T.; Gimona, M. Ca ${ }^{2+}$-dependent Association of S100A6 (Calcyclin) with the Plasma Membrane and the Nuclear Envelope. J. Biol. Chem. 1999, 274, 31593-31596. [CrossRef]

98. Komatsu, K.; Andoh, A.; Ishiguro, S.; Suzuki, N.; Hunai, H.; Kobune-Fujiwara, Y.; Kameyama, M.; Miyoshi, J.; Akedo, H.; Nakamura, H. Increased expression of S100A6 (Calcyclin), a calcium-binding protein of the S100 family, in human colorectal adenocarcinomas. Clin. Cancer Res. 2000, 6, 172-177.

99. De Petris, L.; Orre, L.M.; Kanter, L.; Pernemalm, M.; Koyi, H.; Lewensohn, R.; Lehtiö, J. Tumor expression of S100A6 correlates with survival of patients with stage I non-small-cell lung cancer. Lung Cancer 2009, 63, 410-417. [CrossRef] [PubMed]

100. Ohuchida, K.; Mizumoto, K.; Yu, J.; Yamaguchi, H.; Konomi, H.; Nagai, E.; Yamaguchi, K.; Tsuneyoshi, M.; Tanaka, M. S100A6 Is Increased in a Stepwise Manner during Pancreatic Carcinogenesis: Clinical Value of Expression Analysis in 98 Pancreatic Juice Samples. Cancer Epidemiol. Biomark. Prev. 2007, 16, 649-654. [CrossRef]

101. Yang, Y.Q.; Zhang, L.J.; Dong, H.; Jiang, C.L.; Zhu, Z.G.; Wu, J.X.; Wu, Y.L.; Han, J.S.; Xiao, H.S.; Gao, H.J.; et al. Upregulated expression of S100A6 in human gastric cancer. J. Dig. Dis. 2007, 8, 186-193. [CrossRef]

102. Wolf, R.; Howard, O.M.Z.; Dong, H.-F.; Voscopoulos, C.; Boeshans, K.; Winston, J.; Divi, R.; Gunsior, M.; Goldsmith, P.; Ahvazi, B.; et al. Chemotactic Activity of S100A7 (Psoriasin) Is Mediated by the Receptor for Advanced Glycation End Products and Potentiates Inflammation with Highly Homologous but Functionally Distinct S100A. J. Immunol. 2008, 181, 1499-1506. [CrossRef]

103. Brandtzaeg, P.; Gabrielsen, T.-Ø.; Dale, I.; Múller, F.; Steinbakk, M.; Fagerhol, M.K. The Leucocyte Protein L1 (Calprotectin): A Putative Nonspecific Defence Factor at Epithelial Surfaces. In Chemistry and Biology of Pteridines and Folates; Springer Science and Business Media LLC: Berlin/Heidelberg, Germany, 1995; Volume 371, pp. 201-206.

104. Murao, S.; Collart, F.; Huberman, E. A protein complex expressed during terminal differentiation of monomyelocytic cells is an inhibitor of cell growth. Cell Growth Differ. Mol. Boil. J. Am. Assoc. Cancer Res. 1990, 1, 447-454.

105. Kelly, S.E.; Jones, D.B.; Fleming, S. Calgranulin expression in inflammatory dermatoses. J. Pathol. 1989, 159, 17-21. [CrossRef] [PubMed]

106. Korndörfer, I.P.; Brueckner, F.; Skerra, A. The Crystal Structure of the Human (S100A8/S100A9)2 Heterotetramer, Calprotectin, Illustrates how Conformational Changes of Interacting $\alpha$-Helices Can Determine Specific Association of Two EF-hand Proteins. J. Mol. Biol. 2007, 370, 887-898. [CrossRef] [PubMed]

107. Lügering, N.; Stoll, R.; Kucharzik, T.; Schmid, K.W.; Rohlmann, G.; Burmeister, G.; Sorg, C.; Domschke, W. Immunohistochemical distribution and serum levels of the $\mathrm{Ca}^{2+}$-binding proteins MRP8, MRP14 and their heterodimeric form MRP8/14 in Crohn's disease. Digestion 1995, 56, 406-414. [CrossRef] [PubMed]

108. Ehlermann, P.; Eggers, K.; Bierhaus, A.; Most, P.; Weichenhan, D.; Greten, J.; Nawroth, P.P.; A. Katus, H.; Remppis, A. Increased proinflammatory endothelial response to S100A8/A9 after preactivation through advanced glycation end products. Cardiovasc. Diabetol. 2006, 5, 6. [CrossRef]

109. Yong, H.-Y.; Moon, A. Roles of calcium-binding proteins, S100A8 and S100A9, in invasive phenotype of human gastric cancer cells. Arch. Pharmacal Res. 2007, 30, 75-81. [CrossRef]

110. Kerkhoff, C.; Klempt, M.; Sorg, C. Novel insights into structure and function of MRP8 (S100A8) and MRP14 (S100A9). Biochim. Biophys. Acta (BBA)-Bioenerg. 1998, 1448, 200-211. [CrossRef] 
111. Hermani, A.; de Servi, B.; Medunjanin, S.; Tessier, P.A.; Mayer, D. S100A8 and S100A9 activate MAP kinase and NF-кB signaling pathways and trigger translocation of RAGE in human prostate cancer cells. Exp. Cell Res. 2006, 312, 184-197. [CrossRef]

112. Stulík, J.; Österreicher, J.; Koupilová, K.; Knížek, J.; Macela, A.; Bureš, J.; Jandík, P.; Langr, F.; Dědič, K.; Jungblut, P.R. The analysis of S100A9 and S100A8 expression in matched sets of macroscopically normal colon mucosa and colorectal carcinoma: The S100A9 and S100A8 positive cells underlie and invade tumor mass. Electrophoresis 1999, 20, 1047-1054. [CrossRef]

113. Hermani, A.; Hess, J.; de Servi, B.; Medunjanin, S.; Grobholz, R.; Trojan, L.; Angel, P.; Mayer, D. Calcium-binding proteins S100A8 and S100A9 as novel diagnostic markers in human prostate cancer. Clin. Cancer Res. 2005, 11, 5146-5152. [CrossRef]

114. Ghavami, S.; Rashedi, I.; Dattilo, B.M.; Eshraghi, M.; Chazin, W.J.; Hashemi, M.; Wesselborg, S.; Kerkhoff, C.; Los, M. S100A8/ A9 at low concentration promotes tumor cell growth via RAGE ligation and MAP kinase-dependent pathway. J. Leukoc. Biol. 2008, 83, 1484-1492. [CrossRef] [PubMed]

115. Sunahori, K.; Yamamura, M.; Yamana, J.; Takasugi, K.; Kawashima, M.; Yamamoto, H.; Chazin, W.J.; Nakatani, Y.; Yui, S.; Makino, $\mathrm{H}$. The S100A8/ A9 heterodimer amplifies proinflammatory cytokine production by macrophages via activation of nuclear factor kappa B and p38 mitogen-activated protein kinase in rheumatoid arthritis. Arthritis Res. 2006, 8, R69. [CrossRef] [PubMed]

116. Rehman, I.; Azzouzi, A.R.; Cross, S.S.; Deloulme, J.C.; Catto, J.W.; Wylde, N.; Larre, S.; Champigneuille, J.; Hamdy, F.C. Dysregulated expression of S100A11 (calgizzarin) in prostate cancer and precursor lesions. Hum. Pathol. 2004, 35, 1385-1391. [CrossRef]

117. Cross, S.S.; Hamdy, F.C.; Deloulme, J.C.; Rehman, I. Expression of S100 proteins in normal human tissues and common cancers using tissue microarrays: S100A6, S100A8, S100A9 and S100A11 are all overexpressed in common cancers. Histopathology 2005, 46, 256-269. [CrossRef] [PubMed]

118. Ohuchida, K.; Mizumoto, K.; Ohhashi, S.; Yamaguchi, H.; Konomi, H.; Nagai, E.; Yamaguchi, K.; Tsuneyoshi, M.; Tanaka, M. S100A11, A Putative Tumor Suppressor Gene, Is Overexpressed in Pancreatic Carcinogenesis. Clin. Cancer Res. 2006, 12, 5417-5422. [CrossRef]

119. Memon, A.; Sorensen, B.; Meldgaard, P.; Fokdal, L.; Thykjaer, T.; Nexo, E. Down-regulation of S100C is associated with bladder cancer progression and poor survival. Clin. Cancer Res. 2005, 11, 606-611.

120. Kondo, A.; Sakaguchi, M.; Makino, E.; Namba, M.; Okada, S.; Huh, N.-H. Localization of S100C immunoreactivity in various human tissues. Acta Med. Okayama 2002, 56, 31-34.

121. Cecil, D.L.; Johnson, K.; Rediske, J.; Lotz, M.; Schmidt, A.M.; Terkeltaub, R. Inflammation-Induced Chondrocyte Hypertrophy Is Driven by Receptor for Advanced Glycation End Products. J. Immunol. 2005, 175, 8296-8302. [CrossRef]

122. Foell, D.; Ichida, F.; Vogl, T.; Yu, X.; Chen, R.; Miyawaki, T.; Sorg, C.; Roth, J. S100A12 (EN-RAGE) in monitoring Kawasaki disease. Lancet 2003, 361, 1270-1272. [CrossRef]

123. Foell, D.; Kane, D.; Bresnihan, B.; Vogl, T.; Nacken, W.; Sorg, C.; FitzGerald, O.; Roth, J. Expression of the pro-inflammatory protein S100A12 (EN-RAGE) in rheumatoid and psoriatic arthritis. Rheumatology 2003, 42, 1383-1389. [CrossRef]

124. Foell, D.; Kucharzik, T.; Kraft, M.; Vogl, T.; Sorg, C.; Domschke, W.; Roth, J. Neutrophil derived human S100A12 (EN-RAGE) is strongly expressed during chronic active inflammatory bowel disease. Gut 2003, 52, 847-853. [CrossRef] [PubMed]

125. Foell, D.; Seeliger, S.; Vogl, T.; Koch, H.-G.; Maschek, H.; Harms, E.; Sorg, C.; Roth, J. Expression of S100A12 (EN-RAGE) in cystic fibrosis. Thorax 2003, 58, 613-617. [CrossRef] [PubMed]

126. Mori, Y.; Kosaki, A.; Kishimoto, N.; Kimura, T.; Iida, K.; Fukui, M.; Nakajima, F.; Nagahara, M.; Urakami, M.; Iwasaka, T.; et al. Increased Plasma S100A12 (EN-RAGE) Levels in Hemodialysis Patients with Atherosclerosis. Am. J. Nephrol. 2009, $29,18-24$. [CrossRef] [PubMed]

127. Pietzsch, J.; Hoppmann, S. Human S100A12: A novel key player in inflammation? Amino Acids 2008, 36, 381-389. [CrossRef]

128. Mikkelsen, S.E.; Novitskaya, V.; Kriajevska, M.; Berezin, V.; Bock, E.; Norrild, B.; Lukanidin, E. S100A12 protein is a strong inducer of neurite outgrowth from primary hippocampal neurons. J. Neurochem. 2008, 79, 767-776. [CrossRef]

129. Hsieh, H.-L.; Schäfer, B.W.; Weigle, B.; Heizmann, C.W. S100 protein translocation in response to extracellular S100 is mediated by receptor for advanced glycation endproducts in human endothelial cells. Biochem. Biophys. Res. Commun. 2004, 316, 949-959. [CrossRef]

130. Wicki, R.; Schäfer, B.W.; Erne, P.; Heizmann, C.W. Characterization of the human and mouse cDNAs coding for S100A13, a new member of the S100 protein family. Biochem. Biophys Res. Commun. 1996, 227, 594-599. [CrossRef]

131. Ridinger, K.; Schäfer, B.W.; Durussel, I.; Cox, J.A.; Heizmann, C.W. S100ABiochemical characterization and subcellular localization in different cell lines. J. Biol. Chem. 2000, 275, 8686-8694. [CrossRef]

132. Landriscina, M.; Schinzari, G.; Di Leonardo, G.; Quirino, M.; Cassano, A.; D’Argento, E.; Lauriola, L.; Scerrati, M.; Prudovsky, I.; Barone, C. S100A13, a new marker of angiogenesis in human astrocytic gliomas. J. Neuro-Oncol. 2006, 80, 251-259. [CrossRef]

133. Pierce, A.; Barron, N.; Linehan, R.; Ryan, E.; O’Driscoll, L.; Daly, C.; Clynes, M. Identification of a novel, functional role for S100A13 in invasive lung cancer cell lines. Eur. J. Cancer 2008, 44, 151-159. [CrossRef]

134. Parkkila, S.; Pan, P.-W.; Ward, A.; Gibadulinova, A.; Oveckova, I.; Pastorekova, S.; Pastorek, J.; Martinez, A.R.; Helin, H.O.; Isola, J. The calcium-binding protein S100P in normal and malignant human tissues. BMC Clin. Pathol. 2008, 8, 2. [CrossRef]

135. Arumugam, T.; Simeone, D.M.; Van Golen, K.; Logsdon, C.D. S100P Promotes Pancreatic Cancer Growth, Survival, and Invasion. Clin. Cancer Res. 2005, 11, 5356-5364. [CrossRef] 
136. Da Silva, I.D.G.; Hu, Y.F.; Russo, I.H.; Ao, X.; Salicioni, A.M.; Yang, X.; Russo, J. S100P calcium-binding protein overexpression is associated with immortalization of human breast epithelial cells in vitro and early stages of breast cancer development in vivo. Int. J. Oncol. 2000, 16, 231-240. [CrossRef]

137. Arumugam, T.; Simeone, D.M.; Schmidt, A.M.; Logsdon, C.D. S100P Stimulates Cell Proliferation and Survival via Receptor for Activated Glycation End Products (RAGE). J. Biol. Chem. 2004, 279, 5059-5065. [CrossRef]

138. Müller-Knapp, S.; Scaffidi, P.; Degryse, B.; Bonaldi, T.; Ronfani, L.; Agresti, A.; Beltrame, M.; Bianchi, M.E. NEW EMBO MEMBERS' REVIEW: The double life of HMGB1 chromatin protein: Architectural factor and extracellular signal. EMBO J. 2001, 20, 4337-4340. [CrossRef]

139. Tian, J.; Avalos, A.M.; Mao, S.-Y.; Chen, B.; Senthil, K.; Wu, H.; Parroche, P.; Drabic, S.; Golenbock, D.T.; Sirois, C.M.; et al. Toll-like receptor 9-dependent activation by DNA-containing immune complexes is mediated by HMGB1 and RAGE. Nat. Immunol. 2007, 8, 487-496. [CrossRef]

140. Tang, D.; Kang, R.; Iii, H.J.Z.; Lotze, M.T. High-mobility group box 1 and cancer. Biochim. Biophys. Acta (BBA)-Bioenerg. 2010, 1799, 131-140. [CrossRef]

141. Wang, H.; Yang, H.; Tracey, K.J. Extracellular role of HMGB1 in inflammation and sepsis. J. Intern. Med. 2004, 255, 320-331. [CrossRef]

142. Andersson, U.; Tracey, K.J. HMGB1 as a mediator of necrosis-induced inflammation and a therapeutic target in arthritis. Rheum. Dis. Clin. N. Am. 2004, 30, 627-637. [CrossRef] [PubMed]

143. Enokido, Y.; Yoshitake, A.; Ito, H.; Okazawa, H. Age-dependent change of HMGB1 and DNA double-strand break accumulation in mouse brain. Biochem. Biophys. Res. Commun. 2008, 376, 128-133. [CrossRef] [PubMed]

144. Sparvero, L.J.; Asafu-Adjei, D.; Kang, R.; Tang, D.; Amin, N.; Im, J.; Rutledge, R.; Lin, B.; Amoscato, A.A.; Zeh, H.J.; et al. RAGE (Receptor for Advanced Glycation Endproducts), RAGE Ligands, and their role in Cancer and Inflammation. J. Transl. Med. 2009, 7, 17-21. [CrossRef] [PubMed]

145. Lotze, M.T.; Demarco, R.A. Dealing with death: HMGB1 as a novel target for cancer therapy. Curr. Opin. Investig. Drugs (Lond. Engl. 2000) 2003, 4, 1405-1409.

146. Sims, G.P.; Rowe, D.C.; Rietdijk, S.T.; Herbst, R.; Coyle, A.J. HMGB1 and RAGE in Inflammation and Cancer. Annu. Rev. Immunol. 2010, 28, 367-388. [CrossRef]

147. Kuniyasu, H.; Chihara, Y.; Takahashi, T. Co-expression of receptor for advanced glycation end products and the ligand amphoterin associates closely with metastasis of colorectal cancer. Oncol. Rep. 2003, 10, 445-448. [CrossRef]

148. Huang, C.-Y.; Chiang, S.-F.; Chen, W.T.-L.; Ke, T.-W.; Chen, T.-W.; You, Y.-S.; Lin, C.-Y.; Chao, K.S.C. HMGB1 promotes ERKmediated mitochondrial Drp1 phosphorylation for chemoresistance through RAGE in colorectal cancer. Cell Death Dis. 2018, 9, 1-15. [CrossRef]

149. Mills, G.B.; Moolenaar, W.H. The emerging role of lysophosphatidic acid in cancer. Nat. Rev. Cancer 2003, 3, 582-591. [CrossRef]

150. Glade, M.J.; Smith, K. Phosphatidylserine and the human brain. Nutrition 2015, 31, 781-786. [CrossRef]

151. Sakaguchi, M.; Murata, H.; Yamamoto, K.-I.; Ono, T.; Sakaguchi, Y.; Motoyama, A.; Hibino, T.; Kataoka, K.; Huh, N.-H. TIRAP, an Adaptor Protein for TLR2/4, Transduces a Signal from RAGE Phosphorylated upon Ligand Binding. PLoS ONE 2011, 6, e23132. [CrossRef]

152. Gassiorowski, K.; Brokos, B.; Echeverria, V.; Barreto, G.E.; Leszek, J. RAGE-TLR Crosstalk Sustains Chronic Inflammation in Neurodegeneration. Mol. Neurobiol. 2018, 55, 1463-1476. [CrossRef]

153. Wang, L.; Wu, J.; Guo, X.; Huang, X.; Huang, Q. RAGE plays a role in LPS-induced NF- $\mathrm{BB}$ activation and endothelial hyperpermeability. Sensors 2017, 17, 722. [CrossRef]

154. Rouhiainen, A.; Kuja-Panula, J.; Tumova, S.; Rauvala, H. RAGE-mediated cell signaling. Calcium-Bind. Proteins RAGE. 2013, 239-263. [CrossRef]

155. Yamamoto, K.-I.; Murata, H.; Putranto, E.W.; Kataoka, K.; Motoyama, A.; Hibino, T.; Inoue, Y.; Sakaguchi, M.; Huh, N.-H. DOCK7 is a critical regulator of the RAGE-Cdc42 signaling axis that induces formation of dendritic pseudopodia in human cancer cells. Oncol. Rep. 2012, 29, 1073-1079. [CrossRef]

156. Touré, F.; Fritz, G.; Li, Q.; Rai, V.; Daffu, G.; Zou, Y.S.; Rosario, R.; Ramasamy, R.; Alberts, A.S.; Yan, S.F.; et al. Formin mDia1 Mediates Vascular Remodeling via Integration of Oxidative and Signal Transduction Pathways. Circ. Res. 2012, 110, $1279-1293$. [CrossRef]

157. Bianchi, R.; Kastrisianaki, E.; Giambanco, I.; Donato, R. S100B Protein Stimulates Microglia Migration via RAGE-dependent Up-regulation of Chemokine Expression and Release. J. Biol. Chem. 2011, 286, 7214-7226. [CrossRef]

158. Xu, Y.; Toure, F.; Qu, W.; Lin, L.; Song, F.; Shen, X.; Rosario, R.; Garcia, J.; Schmidt, A.M.; Yan, S.-F. Advanced Glycation End Product (AGE)-Receptor for AGE (RAGE) Signaling and Up-regulation of Egr-1 in Hypoxic Macrophages. J. Biol. Chem. 2010, 285, 23233-23240. [CrossRef]

159. Wendt, T.; Harja, E.; Bucciarelli, L.; Qu, W.; Lu, Y.; Rong, L.L.; Jenkins, D.G.; Stein, G.; Schmidt, A.M.; Yan, S.F. RAGE modulates vascular inflammation and atherosclerosis in a murine model of type 2 diabetes. Atherosclerosis 2006, 185, 70-77. [CrossRef]

160. Ahmed, N. Advanced glycation endproducts-Role in pathology of diabetic complications. Diabetes Res. Clin. Pract. 2005, 67, 3-21. [CrossRef]

161. Chuah, Y.K.; Basir, R.; Talib, H.; Tie, T.H.; Nordin, N. Receptor for Advanced Glycation End Products and Its Involvement in Inflammatory Diseases. Int. J. Inflamm. 2013, 2013, 1-15. [CrossRef] [PubMed] 
162. Eleazu, C.; Omar, N.; Lim, O.Z.; Yeoh, B.S.; Hussain, N.H.N.; Mohamed, M. Obesity and comorbidity: Could simultaneous targeting of esRAGE and sRAGE be the panacea? Front. Physiol. 2019, 10, 787. [CrossRef] [PubMed]

163. Liu, Y.; Yu, M.; Zhang, Z.; Yu, Y.; Chen, Q.; Zhang, W.; Zhao, X. Blockade of receptor for advanced glycation end products protects against systolic overload-induced heart failure after transverse aortic constriction in mice. Eur. J. Pharmacol. 2016, 791, 535-543. [CrossRef]

164. Warboys, C.M.; Toh, H.-B.; Fraser, P.A. Role of NADPH Oxidase in Retinal Microvascular Permeability Increase by RAGE Activation. Investig. Opthalmol. Vis. Sci. 2009, 50, 1319-1328. [CrossRef]

165. Jensen, L.J.N.; Flyvbjerg, A.; Bjerre, M. Soluble Receptor for Advanced Glycation End Product: A Biomarker for Acute Coronary Syndrome. BioMed Res. Int. 2015, 2015, 815942. [CrossRef]

166. Ray, R.; Juranek, J.K.; Rai, V. RAGE axis in neuroinflammation, neurodegeneration and its emerging role in the pathogenesis of amyotrophic lateral sclerosis. Neurosci. Biobehav. Rev. 2016, 62, 48-55. [CrossRef]

167. Bettiga, A.; Fiorio, F.; Di Marco, F.; Trevisani, F.; Romani, A.; Porrini, E.; Salonia, A.; Montorsi, F.; Vago, R. The Modern Western Diet Rich in Advanced Glycation End-Products (AGEs): An Overview of Its Impact on Obesity and Early Progression of Renal Pathology. Nutrition 2019, 11, 1748. [CrossRef] [PubMed]

168. Oczypok, E.A.; Perkins, T.N.; Oury, T.D. All the "RAGE" in lung disease: The receptor for advanced glycation endproducts (RAGE) is a major mediator of pulmonary inflammatory responses. Paediatr. Respir. Rev. 2017, 23, 40-49. [CrossRef]

169. Liu, Y.; Liang, C.; Liu, X.; Liao, B.; Pan, X.; Ren, Y.; Fan, M.; Li, M.; He, Z.; Wu, J.; et al. AGEs increased migration and inflammatory responses of adventitial fibroblasts via RAGE, MAPK and NF-kB pathways. Atherosclerosis 2010, 208, 34-42. [CrossRef]

170. Yeh, C.-H.; Sturgis, L.; Haidacher, J.; Zhang, X.-N.; Sherwood, S.J.; Bjercke, R.J.; Juhasz, O.; Crow, M.T.; Tilton, R.G.; Denner, L. Requirement for p38 and p44/p42 mitogen-activated protein kinases in RAGE-mediated nuclear factor- $\mathrm{kB}$ transcriptional activation and cytokine secretion. Diabetes 2001, 50, 1495-1504. [CrossRef] [PubMed]

171. Kislinger, T.; Tanji, N.; Wendt, T.; Qu, W.; Lu, Y.; Ferran, L.J.; Taguchi, A.; Olson, K.; Bucciarelli, L.; Goova, M.; et al. Receptor for Advanced Glycation End Products Mediates Inflammation and Enhanced Expression of Tissue Factor in Vasculature of Diabetic Apolipoprotein E-Null Mice. Arter. Thromb. Vasc. Biol. 2001, 21, 905-910. [CrossRef]

172. Bangert, A.; Andrassy, M.; Müller, A.-M.; Bockstahler, M.; Fischer, A.; Volz, C.H.; Leib, C.; Göser, S.; Korkmaz-Icöz, S.; Zittrich, S Critical role of RAGE and HMGB1 in inflammatory heart disease. Proc. Natl. Acad. Sci. USA 2016, 113, E155-E164. [CrossRef] [PubMed]

173. Kay, A.M.; Simpson, C.L.; Stewart, J.A. The Role of AGE/RAGE Signaling in Diabetes-Mediated Vascular Calcification. J. Diabetes Res. 2016, 2016, 1-8. [CrossRef]

174. Tanikawa, T.; Okada, Y.; Tanikawa, R.; Tanaka, Y. Advanced Glycation End Products Induce Calcification of Vascular Smooth Muscle Cells through RAGE/p38 MAPK. J. Vasc. Res. 2009, 46, 572-580. [CrossRef]

175. Coughlan, M.T.; Thorburn, D.; Penfold, S.A.; Laskowski, A.; Harcourt, B.E.; Sourris, K.C.; Tan, A.L.; Fukami, K.; Thallas-Bonke, V.; Nawroth, P.P.; et al. RAGE-Induced Cytosolic ROS Promote Mitochondrial Superoxide Generation in Diabetes. J. Am. Soc. Nephrol. 2009, 20, 742-752. [CrossRef]

176. Bu, D.-X.; Rai, V.; Shen, X.; Rosario, R.; Lu, Y.; Dagati, V.D.; Yan, S.F.; Friedman, R.A.; Nuglozeh, E.; Schmidt, A.M. Activation of the ROCK1 Branch of the Transforming Growth Factor- $\beta$ Pathway Contributes to RAGE-Dependent Acceleration of Atherosclerosis in Diabetic ApoE-Null Mice. Circ. Res. 2010, 106, 1040-1051. [CrossRef]

177. Cepas, V.; Collino, M.; Mayo, J.C.; Sainz, R.M. Redox Signaling and Advanced Glycation Endproducts (AGEs) in Diet-Related Diseases. Antioxidants 2020, 9, 142. [CrossRef]

178. Juranek, J.K.; Kothary, P.; Mehra, A.; Hays, A.; Iii, T.H.B.; Schmidt, A.M. Increased expression of the receptor for advanced glycation end-products in human peripheral neuropathies. Brain Behav. 2013, 3, 701-709. [CrossRef]

179. Williams, N.; Okun, M. Deep brain stimulation (DBS) at the interface of neurology and psychiatry. J. Clin. Investig. 2013, 123, 4546-4556. [CrossRef]

180. Kouidrat, Y.; Amad, A.; Arai, M.; Miyashita, M.; Lalau, J.-D.; Loas, G.; Itokawa, M. Advanced glycation end products and schizophrenia: A systematic review. J. Psychiatr. Res. 2015, 66-67, 112-117. [CrossRef]

181. MacLean, M.; Derk, J.; Ruiz, H.H.; Juranek, J.; Ramasamy, R.; Schmidt, A.M. The Receptor for Advanced Glycation End Products (RAGE) and DIAPH1: Implications for vascular and neuroinflammatory dysfunction in disorders of the central nervous system. Neurochem. Int. 2019, 126, 154-164. [CrossRef]

182. Richard, S.A.; Sackey, M.; Su, Z.; Xu, H. Pivotal neuroinflammatory and therapeutic role of high mobility group box 1 in ischemic stroke. Biosci. Rep. 2017, 37. [CrossRef]

183. Sasaki, N.; Toki, S.; Chowei, H.; Saito, T.; Nakano, N.; Hayashi, Y.; Takeuchi, M.; Makita, Z. Immunohistochemical distribution of the receptor for advanced glycation end products in neurons and astrocytes in Alzheimer's disease. Brain Res. 2001, 888, 256-262. [CrossRef]

184. Ding, Q.; Keller, J.N. Evaluation of rage isoforms, ligands, and signaling in the brain. Biochim. Biophys. Acta (BBA)-Bioenerg. 2005, 1746, 18-27. [CrossRef]

185. Deane, R.J. Is RAGE still a therapeutic target for Alzheimer's disease? Futur. Med. Chem. 2012, 4, 915-925. [CrossRef]

186. Deane, R.; Singh, I.; Sagare, A.P.; Bell, R.D.; Ross, N.T.; LaRue, B.; Love, R.; Perry, S.; Paquette, N.; Deane, R.J.; et al. A multimodal RAGE-specific inhibitor reduces amyloid $\beta$-mediated brain disorder in a mouse model of Alzheimer disease. J. Clin. Investig. 2012, 122, 1377-1392. [CrossRef] 
187. Bianchi, R.; Giambanco, I.; Donato, R. S100B/RAGE-dependent activation of microglia via NF-kB and AP-1: Co-regulation of COX-2 expression by S100B, IL-1 $\beta$ and TNF- $\alpha$. Neurobiol. Aging 2010, 31, 665-677. [CrossRef]

188. Kang, R.; Tang, D.; Schapiro, N.E.; Livesey, K.M.; Farkas, A.; Loughran, P.; Bierhaus, A.; Lotze, M.T.; Zeh, H.J. The receptor for advanced glycation end products (RAGE) sustains autophagy and limits apoptosis, promoting pancreatic tumor cell survival. Cell Death Differ. 2010, 17, 666-676. [CrossRef]

189. Logsdon, C.D.; Fuentes, M.K.; Huang, E.H.; Arumugam, T. RAGE and RAGE ligands in cancer. Curr. Mol. Med. 2007, 7, 777-789. [CrossRef]

190. Kwak, T.; Drews-Elger, K.; Ergonul, A.; Miller, P.C.; Braley, A.; Hwang, G.H.; Zhao, D.; Besser, A.; Yamamoto, Y.; El-Ashry, D.; et al. Targeting of RAGE-ligand signaling impairs breast cancer cell invasion and metastasis. Oncogene 2017, 36, 1559-1572. [CrossRef]

191. Kalea, A.Z.; See, F.; Harja, E.; Arriero, M.; Schmidt, A.M.; Hudson, B.I. Alternatively Spliced RAGEv1 Inhibits Tumorigenesis through Suppression of JNK Signaling. Cancer Res. 2010, 70, 5628-5638. [CrossRef]

192. Sorci, G.; Riuzzi, F.; Arcuri, C.; Tubaro, C.; Bianchi, R.; Giambanco, I.; Donato, R. S100B protein in tissue development, repair and regeneration. World J. Biol. Chem. 2013, 4, 1-12. [CrossRef]

193. Matou-Nasri, S.; Sharaf, H.; Wang, Q.; Almobadel, N.; Rabhan, Z.; Al-Eidi, H.; Bin Yahya, W.; Trivilegio, T.; Ali, R.; Al-Shanti, N.; et al. Biological impact of advanced glycation endproducts on estrogen receptor-positive MCF-7 breast cancer cells. Biochim. Biophys. Acta (BBA)-Mol. Basis Dis. 2017, 1863, 2808-2820. [CrossRef]

194. Azizan, N.; Suter, M.A.; Liu, Y.; Logsdon, C.D. RAGE maintains high levels of NFkB and oncogenic Kras activity in pancreatic cancer. Biochem. Biophys. Res. Commun. 2017, 493, 592-597. [CrossRef]

195. Syed, D.N.; Aljohani, A.; Waseem, D.; Mukhtar, H. Ousting RAGE in melanoma: A viable therapeutic target? Semin. Cancer Biol. 2018, 49, 20-28. [CrossRef] [PubMed]

196. Deng, R.; Mo, F.; Chang, B.; Zhang, Q.; Ran, H.; Yang, S.; Zhu, Z.; Hu, L.; Su, Q. Glucose-derived AGEs enhance human gastric cancer metastasis through RAGE/ERK/Sp1/MMP2 cascade. Oncotarget 2017, 8, 104216-104226. [CrossRef] [PubMed]

197. Somensi, N.; Brum, P.O.; Ramos, V.d.; Gasparotto, J.; Zanotto-Filho, A.; Rostirolla, D.C.; Morrone, M.d.; Moreira, J.C.F.; Gelain, D.P. Extracellular HSP70 Activates ERK1/2, NF-kB and Pro-Inflammatory Gene Transcription Through Binding with RAGE in A549 Human Lung Cancer Cells. Cell Physiol. Biochem. 2017, 42, 2507-2522. [CrossRef]

198. Ahmad, S.; Khan, H.; Siddiqui, Z.; Khan, M.Y.; Rehman, S.; Shahab, U.; Godovikova, T.; Silnikov, V.; Moinuddin. AGEs, RAGEs and s-RAGE; friend or foe for cancer. Semin. Cancer Biol. 2018, 49, 44-55. [CrossRef]

199. Kolonin, M.G.; Sergeeva, A.; Staquicini, D.I.; Smith, T.L.; Tarleton, C.A.; Molldrem, J.J.; Sidman, R.L.; Marchiò, S.; Pasqualini, R.; Arap, W. Interaction between Tumor Cell Surface Receptor RAGE and Proteinase 3 Mediates Prostate Cancer Metastasis to Bone. Cancer Res. 2017, 77, 3144-3150. [CrossRef]

200. Aboushousha, T.; Mamdouh, S.; Hamdy, H.; Helal, N.; Khorshed, F.; Safwat, G.; Seleem, M. Immunohistochemical and Biochemical Expression Patterns of TTF-1, RAGE, GLUT-1 and SOX2 in HCV-Associated Hepatocellular Carcinomas. Asian Pac. J. Cancer Prev. 2018, 19, 219-227. [CrossRef]

201. Chen, W.-W.; Guo, Q.; Zhang, Z.-D.; Hu, W.-M. Effects of RAGE on Cell Proliferation and Tumor Growth in Pancreatic Cancer. J. Sichuan Univ. Med Sci. Ed. 2017, 48, 46-51.

202. Yu, Y.X.; Pan, W.C.; Cheng, Y.F. Silencing of advanced glycosylation and glycosylation and product-specific receptor (RAGE) inhibits the metastasis and growth of non-small cell lung cancer. Am. J. Transl. Res. 2017, 9, 2760-2774. [PubMed]

203. Adamopoulos, C.; Piperi, C.; Gargalionis, A.N.; Dalagiorgou, G.; Spilioti, E.; Korkolopoulou, P.; Diamanti-Kandarakis, E.; Papavassiliou, A.G. Advanced glycation end products upregulate lysyl oxidase and endothelin-1 in human aortic endothelial cells via parallel activation of ERK1/2-NF-kB and JNK-AP-1 signaling pathways. Cell Mol. Life Sci. 2016, 73, 1685-1698. [CrossRef] [PubMed]

204. Cai, W.; Duan, X.-M.; Liu, Y.; Yu, J.; Tang, Y.-L.; Liu, Z.-L.; Jiang, S.; Zhang, C.-P.; Liu, J.-Y.; Xu, J.-X. Uric Acid Induces Endothelial Dysfunction by Activating the HMGB1/RAGE Signaling Pathway. BioMed Res. Int. 2017, 2017, 1-11. [CrossRef]

205. Gardner, T.W.; Antonetti, D.A.; Barber, A.J.; LaNoue, K.F.; Levison, S.W. Diabetic retinopathy: More than meets the eye. Surv. Ophthalmol. 2002, 47 (Suppl. 2), S253-S262. [CrossRef]

206. McVicar, C.M.; Ward, M.; Colhoun, L.M.; Guduric-Fuchs, J.; Bierhaus, A.; Fleming, T.; Schlotterer, A.; Kolibabka, M.; Hammes, H.-P.; Chen, M.; et al. Role of the receptor for advanced glycation endproducts (RAGE) in retinal vasodegenerative pathology during diabetes in mice. Diabetologia 2015, 58, 1129-1137. [CrossRef] [PubMed]

207. Kaji, Y.; Usui, T.; Ishida, S.; Yamashiro, K.; Moore, T.C.B.; Moore, J.; Yamamoto, Y.; Yamamoto, H.; Adamis, A.P. Inhibition of Diabetic Leukostasis and Blood-Retinal Barrier Breakdown with a Soluble Form of a Receptor for Advanced Glycation End Products. Investig. Opthalmol. Vis. Sci. 2007, 48, 858-865. [CrossRef]

208. Barile, G.R.; Pachydaki, S.I.; Tari, S.R.; Lee, S.E.; Donmoyer, C.M.; Ma, W.; Rong, L.L.; Buciarelli, L.G.; Wendt, T.; Ho“ rig, H.; et al. The RAGE Axis in Early Diabetic Retinopathy. Investig. Opthalmol. Vis. Sci. 2005, 46, 2916-2924. [CrossRef]

209. Riuzzi, F.; Chiappalupi, S.; Arcuri, C.; Giambanco, I.; Sorci, G.; Donato, R. S100 proteins in obesity: Liaisons dangereuses. Cell. Mol. Life Sci. 2019, 77, 129-147. [CrossRef]

210. Song, F.; Del Pozo, C.H.; Rosario, R.; Zou, Y.S.; Ananthakrishnan, R.; Xu, X.; Patel, P.R.; Benoit, V.M.; Yan, S.F.; Li, H.; et al. RAGE Regulates the Metabolic and Inflammatory Response to High-Fat Feeding in Mice. Diabetes 2014, 63, 1948-1965. [CrossRef] [PubMed] 
211. Mukherjee, T.K.; Mukhopadhyay, S.; Hoidal, J.R. Implication of receptor for advanced glycation end product (RAGE) in pulmonary health and pathophysiology. Respir. Physiol. Neurobiol. 2008, 162, 210-215. [CrossRef] [PubMed]

212. Bierhaus, A.; Nawroth, P. Multiple levels of regulation determine the role of the receptor for AGE (RAGE) as common soil in inflammation, immune responses and diabetes mellitus and its complications. Diabetologia 2009, 52, 2251-2263. [CrossRef] [PubMed]

213. Catalano, M.; Cortelazzo, A.; Santi, R.; Contino, L.; Demicheli, M.; Yilmaz, Y.; Zorzetto, M.; Campo, I.; Lanati, N.; Emanuele, E. The Pro12Ala polymorphism of peroxisome proliferator-activated receptor- $\gamma 2$ gene is associated with plasma levels of soluble RAGE (Receptor for Advanced Glycation Endproducts) and the presence of peripheral arterial disease. Clin. Biochem. 2008, 41, 981-985. [CrossRef] [PubMed]

214. Jang, Y.; Kim, J.Y.; Kang, S.-M.; Kim, J.-S.; Chae, J.S.; Kim, O.Y.; Koh, S.J.; Lee, H.C.; Ahn, C.W.; Song, Y.D.; et al. Association of the Gly82Ser polymorphism in the receptor for advanced glycation end products (RAGE) gene with circulating levels of soluble RAGE and inflammatory markers in nondiabetic and nonobese Koreans. Metabolism 2007, 56, 199-205. [CrossRef] [PubMed]

215. Weykamp, C. HbA1c: A review of analytical and clinical aspects. AnnLab. Med. 2013, 33, 393. [CrossRef]

216. Constien, R.; Forde, A.; Liliensiek, B.; Gröne, H.J.; Nawroth, P.; Hämmerling, G.; Arnold, B. Characterization of a novel EGFP reporter mouse to monitor Cre recombination as demonstrated by a Tie2 Cre mouse line. Genesis 2001, 30, 36-44. [CrossRef]

217. Al-Robaiy, S.; Weber, B.; Simm, A.; Diez, C.; Rolewska, P.; Silber, R.-E.; Bartling, B. The receptor for advanced glycation end-products supports lung tissue biomechanics. Am. J. Physiol. Cell. Mol. Physiol. 2013, 305, L491-L500. [CrossRef]

218. Park, L.; Raman, K.G.; Lee, K.J.; Lu, Y.; Ferran, L.J., Jr.; Chow, W.S.; Stern, D.; Schmidt, A.M. Suppression of accelerated diabetic atherosclerosis by the soluble receptor for advanced glycation endproducts. Nat. Med. 1998, 4, 1025-1031. [CrossRef]

219. Chen, Y.; Yan, S.S.; Colgan, J.; Zhang, H.-P.; Luban, J.; Schmidt, A.M.; Stern, D.; Herold, K.C. Blockade of late stages of autoimmune diabetes by inhibition of the receptor for advanced glycation end products. J. Immunol. 2004, 173, 1399-1405. [CrossRef] [PubMed]

220. Sabbagh, M.N.; Agro, A.; Bell, J.; Aisen, P.S.; Schweizer, E.; Galasko, D. PF-04494700, an Oral Inhibitor of Receptor for Advanced Glycation End Products (RAGE), in Alzheimer Disease. Alzheimer Dis. Assoc. Disord. 2011, 25, 206-212. [CrossRef]

221. Burstein, A.H.; Grimes, I.; Galasko, D.R.; Aisen, P.S.; Sabbagh, M.; Mjalli, A.M.M. Effect of TTP488 in patients with mild to moderate Alzheimer's disease. BMC Neurol. 2014, 14, 12. [CrossRef]

222. Lee, Y.S.; Kim, H.; Kim, Y.-H.; Roh, E.J.; Han, H.; Shin, K.J. Synthesis and structure-activity relationships of tri-substituted thiazoles as RAGE antagonists for the treatment of Alzheimer's disease. Bioorg. Med. Chem. Lett. 2012, 22, 7555-7561. [CrossRef]

223. Han, Y.T.; Choi, G.-I.; Son, D.; Kim, N.-J.; Yun, H.; Lee, S.; Chang, D.J.; Hong, H.-S.; Kim, H.; Ha, H.-J.; et al. Ligand-Based Design, Synthesis, and Biological Evaluation of 2-Aminopyrimidines, a Novel Series of Receptor for Advanced Glycation End Products (RAGE) Inhibitors. J. Med. Chem. 2012, 55, 9120-9135. [CrossRef] [PubMed]

224. Han, Y.T.; Kim, K.; Choi, G.-I.; An, H.; Son, D.; Kim, H.; Ha, H.-J.; Son, J.-H.; Chung, S.-J.; Park, H.-J.; et al. Pyrazole-5carboxamides, novel inhibitors of receptor for advanced glycation end products (RAGE). Eur. J. Med. Chem. 2014, 79, 128-142. [CrossRef] [PubMed]

225. Choi, K.; Lim, K.S.; Shin, J.; Kim, S.H.; Suh, Y.-G.; Hong, H.-S.; Kim, H.; Ha, H.-J.; Kim, Y.-H.; Lee, J.; et al. 6-Phenoxy-2phenylbenzoxazoles, novel inhibitors of receptor for advanced glycation end products (RAGE). Bioorg. Med. Chem. 2015, 23, 4919-4935. [CrossRef]

226. Zhang, J.; Xu, X.; Rao, N.V.; Argyle, B.; McCoard, L.; Rusho, W.J.; Kennedy, T.P.; Prestwich, G.D.; Krueger, G. Novel Sulfated Polysaccharides Disrupt Cathelicidins, Inhibit RAGE and Reduce Cutaneous Inflammation in a Mouse Model of Rosacea. PLoS ONE 2011, 6, e16658. [CrossRef]

227. Arumugam, T.; Ramachandran, V.; Gomez, S.B.; Schmidt, A.M.; Logsdon, C.D. S100P-Derived RAGE Antagonistic Peptide Reduces Tumor Growth and Metastasis. Clin. Cancer Res. 2012, 18, 4356-4364. [CrossRef]

228. Huttunen, H.J.; Fages, C.; Kuja-Panula, J.; Ridley, A.J.; Rauvala, H. Receptor for advanced glycation end products-binding COOH-terminal motif of amphoterin inhibits invasive migration and metastasis. Cancer Res. 2002, 62, 4805-4811.

229. Yamagishi, S.-I.; Matsui, T. Therapeutic potential of DNA-aptamers raised against AGE-RAGE axis in diabetes-related complications. Curr. Pharm. Design 2018, 24, 2802-2809. [CrossRef] [PubMed]

230. Zheng, J.; Zhu, W.; He, F.; Li, Z.; Cai, N.; Wang, H.-H. An Aptamer-Based Antagonist against the Receptor for Advanced Glycation End-Products (RAGE) Blocks Development of Colorectal Cancer. Mediat. Inflamm. 2021, 2021, 1-8. [CrossRef]

231. Yao, L.; Zhao, H.; Tang, H.; Liang, J.; Liu, L.; Dong, H.; Zou, F.; Cai, S. The receptor for advanced glycation end products is required for $\beta$-catenin stabilization in a chemical-induced asthma model. Br. J. Pharmacol. 2016, 173, 2600-2613. [CrossRef]

232. Mizumoto, S.; Takahashi, J.; Sugahara, K. Receptor for Advanced Glycation End Products (RAGE) Functions as Receptor for Specific Sulfated Glycosaminoglycans, and Anti-RAGE Antibody or Sulfated Glycosaminoglycans Delivered in Vivo Inhibit Pulmonary Metastasis of Tumor Cells. J. Biol. Chem. 2012, 287, 18985-18994. [CrossRef]

233. Yan, Z.; Luo, H.; Xie, B.; Tian, T.; Li, S.; Chen, Z.; Liu, J.; Zhao, X.; Zhang, L.; Deng, Y.; et al. Targeting adaptor protein SLP76 of RAGE as a therapeutic approach for lethal sepsis. Nat. Commun. 2021, 12, 1-14. [CrossRef] [PubMed] 